\title{
Using survey data to resolve the exchange risk exposure puzzle: Evidence from U.S. multinational firms
}

\author{
R. Jongen ${ }^{\mathrm{a}, \mathrm{b}}$, A. Muller ${ }^{\mathrm{c}, \mathrm{d}}$, W.F.C. Verschoor ${ }^{\mathrm{a}, *}$

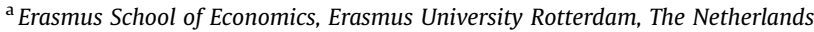 \\ ${ }^{\mathrm{b}}$ De Nederlandsche Bank, The Netherlands \\ ${ }^{\mathrm{c}}$ HEC Management School, University of Liège, Belgium \\ ${ }^{\mathrm{d}}$ Limburg Institute of Financial Economics, Maastricht University, The Netherlands
}

JEL classification:

F3

G12

Keywords:

Exchange risk exposure

Survey-based expectations

Heterogeneity

U.S. multinational firms

\begin{abstract}
A B S T R A C T
This paper examines the effect of unexpected exchange rate movements on U.S. shareholder wealth. Empirical results based on a sample of 634 U.S. multinational firms (1) confirm previously reported evidence that the disaggregation of the worldwide tradeweighted U.S. dollar exchange rate index into seven regionspecific trade-weighted indices increases the precision and significance of exposure estimates; (2) show that models assuming that changes in spot exchange rates are unanticipated are frequently misspecified and, thus, unable to correctly detect the impact of currency movements on firm value; (3) reveal that forward and survey expectations enable us to distinguish between the effect of 'realized' and 'unexpected' currency movements; and (4) reveal that investors making pricing and hedging decisions prefer to use the information contained in short-term forward and survey expectation rates to the information included in long-term forecasts.
\end{abstract}

(c) 2011 Elsevier Ltd. All rights reserved.

\section{Introduction}

Since the breakdown of the Bretton Woods fixed-parity system in the early 1970s, the volatility of exchange rates and its associated risks have become an increasingly important component of international financial management. It is conventional wisdom that exchange rate movements are an important

\footnotetext{
* Corresponding author. Erasmus University Rotterdam, Erasmus School of Economics, PO Box 1738, 3000 DR Rotterdam, The Netherlands. Tel.: +31 104082248 .

E-mail address: verschoor@ese.eur.nl (W.F.C. Verschoor).
} 
major source of macroeconomic uncertainty that influences the profitability and value of firms involved in international activities. Standard economic analysis implies that exchange rate movements affect both the current and future expected cash flows of a firm's operation and its discount rate employed to value the firm. The wide currency fluctuations experienced during the last few decades heightened the interest in the potential vulnerability of multinational firms to foreign exchange rate risk; this issue has spawned a considerable amount of research. Moreover, assessing the sensitivity of firm value to exchange rate changes has been one of the most challenging issues in international financial management over the last two decades.

From a theoretical perspective, exchange rate fluctuations should thus have a significant impact on firm value, regardless of whether the firm is domestically or internationally oriented (Adler and Dumas, 1984; Levi, 1994). Numerous papers analytically focus on the foundations of exchange risk exposure and enhance our understanding of the mechanism through which exchange rate shocks influence firm value. However, in contrast to theoretical expectations, previous empirical evidence on exchange exposure seems conflicting and is mixed at best. While studies have so far documented weak contemporaneous relationships between exchange rates and U.S. stock returns, international evidence focusing on more open economies yields more significant currency risk exposure estimates. A possible rationalization for the difficulties in documenting a measurable impact of foreign exchange risk on stock market values is that firms are aware of their currency exposures and are eliminating foreign currency risk by hedging (Bartov and Bodnar, 1994). Since the long-term effects of exchange rate movements are difficult to ascertain, hedging effectiveness for future cash flows is, however, doubtful. Moreover the underlying assumption that the market should be aware of the impact of companies' foreign exchange risk management practices on an ongoing basis seems unlikely. The counterintuitiveness of empirical findings has thus influenced the developments of new foreign exchange exposure estimation procedures. Starting from the seminal estimation models of Adler and Dumas (1984) and Jorion (1990), subsequent papers study the impact of different variable definitions, model specifications and estimation designs while others exploring the interrelations between exchange rate exposures and economic competitive environments. Even though recent findings generally favor the conclusions that exchange rate fluctuations affect shareholder wealth to some extent, these endeavors nonetheless meet with limited success in documenting the levels of exposures that theoretical research suggests.

Interestingly, the extensive literature on foreign exchange exposure reveals that most empirical studies assumed rational expectations and that 'unanticipated' exchange rate movements may be approximated by changes in 'realized' spot exchange rates. Although the rational expectations hypothesis has considerable appeal as a theoretical model, it does not appear to provide an adequate explanation of exchange rate expectations in most survey-based studies (Jongen et al., 2008). While some empirical studies tend to support the rationality hypothesis (Meese and Rogoff, 1983), the lack of consensus regarding the general outperformance of random walk forecasts over any other alternative exchange rate forecast model (Frankel and Rose, 1995) opens a new and promising research avenue that compares the impact of 'realized' versus 'unanticipated' exchange rate movements on shareholder wealth.

Unlike most previous studies on exchange risk exposure, Amihud (1994) and Gao (2000) recognized the inappropriate use of 'realized' exchange rate movements in testing the relationship between firm value and exchange rates and made a first effort to formally use time-series methods or fundamentalsbased exchange rate models to generate 'unexpected' exchange rate movements. Surprisingly, however, while the foreign exchange rate market literature has for years stirred a considerable amount of interest in the exploration of survey-based expectations in order to understand the behavior of foreign exchange market participants (Frankel and Froot, 1987; Cavaglia et al., 1993, 1994; Jongen et al., 2008), no existing study has yet incorporated the huge amount of information contained in foreign exchange rate market expectations in order to distinguish between 'anticipated' and 'unanticipated' exchange rate movements and verify whether - or not - it is only to the extent that exchange rates move by more or less than had been expected that there are likely to be losses and gains, respectively, in economic value.

In this paper, we recognize the inappropriate use of 'realized' exchange rate movements in testing the relationship between firm value and exchange rates, and propose an empirical model that 
examines in how far exchange rate expectations affect the currency exposure of U.S. shareholder wealth. Rather than analyzing the impact of 'unanticipated' exchange rate movements on firm value by regressing multinational stock returns on 'realized' exchange rate changes, we consider the exchange risk exposure puzzle from a different angle. Motivated by the identification of the differential impact of 'unexpected' exchange rate movements, we examine the impact of 'unanticipated' exchange rate movements on the stock return of U.S. multinational firms by taking a forward and survey-based point of view. More specifically, we analyze the effect of 'unexpected' exchange rate changes on the equity value of a sample of 634 U.S. multinational firms for the period March 1999-December 2009. To compare the relevance of survey-based expectations versus forward rates in capturing the 'unexpected' shock, 'unanticipated' movements are measured with respect to survey-based expectations and forward rates.

The current study complements previous work and makes several main contributions. The comparison of our results with previous U.S. evidence (1) confirms previously reported evidence that the disaggregation of the worldwide trade-weighted U.S. dollar exchange rate index into seven region-specific trade-weighted indices increases the precision and significance of exposure estimates (Khoo, 1994; Ihrig, 2001; Dominguez and Tesar, 2001b; Williamson, 2001); (2) suggests that models assuming that changes in spot exchange rates are unanticipated are frequently misspecified and, thus, unable to correctly detect the impact of currency movements on firm value; (3) shows that - unlike time series and fundamentals-based exchange rate methods for generating forecasts forward rates and survey-based expectations generate 'unexpected' currency movements that are more strongly correlated with firms' stock returns; (4) reveals that truly exogenous individual survey-based expectations are comparatively very informative when it comes to distinguish between 'realized' and 'unexpected' currency movements at the 1-month forecast horizon and (5) suggests that investors making pricing and hedging decisions seem to prefer to use the information contained in short-term exchange market forecasts to the information disclosed in long-term forecasts.

The organization of the paper is as follows. Section 2 reviews theoretical work on the underlying reasons why stock returns fluctuate in response to 'news' about exchange rate movements. Section 3 describes the selection procedure used to form the sample of U.S. multinationals analyzed and details carefully the construction of 'realized' and 'unanticipated' exchange rate series. In Section 4, the empirical methodology used to measure foreign exchange risk exposure is outlined. The empirical findings follow in Section 5, with our concluding remarks in Section 6.

\section{Research design}

Adler and Dumas (1984) can be interpreted as defining foreign exchange risk exposure as the sensitivity of the domestic-currency value of any physical or financial asset to changes in unanticipated exchange rate movements. The exposure of an asset is hence estimated by regressing its domesticcurrency return on the contemporaneous unexpected exchange rate change. ${ }^{1}$ Since other macroeconomic variables may nevertheless simultaneously co-vary with exchange rate movements and asset returns, Jorion (1990) recommends measuring the asset-specific exchange rate sensitivity, called residual exposure, in excess of the total market's reaction to exchange rate movements. Eq. (1) describes his augmented market model that may be regarded as the traditional approach used in the literature to measure foreign risk exposure:

$$
R_{i, t}=\alpha_{i}+\beta_{i} R_{m, t}+\gamma_{i} \theta_{t}+\varepsilon_{i, t}
$$

where $R_{i, t}$ designates the total return of asset $i$ in period $t, R_{\mathrm{m}, t}$ the overall stock market return in period $t, \beta_{i}$ asset $i$ 's return sensitivity to market risk, $\theta_{t}$ the movement in the exchange rate factor in period $t, \gamma_{i}$

\footnotetext{
${ }^{1}$ As strengthened in Jorion (1990) the decomposition of the value of an asset into a component correlated with the unanticipated exchange rate shock no longer implies a casual relationship between unexpected currency movements and asset prices.
} 
asset $i$ 's exposure to the exchange rate independent of the effect these currency movements have on the overall market, and $\varepsilon_{i, t}$ denotes the white noise error term. ${ }^{2}$

It should be emphasized that, according to Adler and Dumas' (1984) seminal definition, foreign exchange risk exposure relates to 'unanticipated' changes in exchange rates. The rationalization for this specification is that current market prices are assumed to have already incorporated currency fluctuations that were anticipated. Consequently it is only to the extent that exchange rates move by more or less than had been expected that there are likely to be losses and gains in economic value. Notice that by relating firm value to innovations in exchange rate movements rather than to total exchange rate movements, we allow investors to get accustomed to the news contained in exchange rate forecasts and hence to incorporate these forecasts in stock returns. According to this approach, firm values are determined in efficient markets where asset prices are adjusted on an instantaneous basis to whatever the market regards as the currently anticipated exchange rate. Thus in Eq. (1) stock returns should not fluctuate in response to total exchange rate movements but in response to 'news' about exchange rate movements.

While there is general consensus regarding this definition of exchange risk exposure, it is striking to observe that most previous empirical studies have used realized changes in spot exchange rates to proxy for unanticipated currency movements. ${ }^{3}$ One possible explanation is that the conventionally defined 'unanticipated' exchange rate changes are difficult to measure, and therefore approximated by realized changes in exchange rates. Moreover the empirical attempts of the 'news' approach using different methods to distinguish between anticipated and unanticipated exchange rate fluctuations provide mixed evidence. Amihud (1994) recommends the use of an AR(1) model to estimate unanticipated currency movements. After having regressed exchange rate variations on their lagged values, he estimates Eq. (1) with $\theta_{t}$ being defined as the residuals of the first regression - considering, hence, the residuals of the first regression as unanticipated exchange rate changes. As this procedure only marginally increases the significance of the results, some authors have constructed the exchange rate factor to be used in Eq. (1) to be orthogonal to fundamental variables. ${ }^{4}$ Gao (2000) proposes, for instance, the regression of exchange rate movements on macroeconomic variables:

$$
\theta_{t}=\lambda_{1}+\sum_{j=1, n 1} \lambda_{R j} I R_{t-j}+\sum_{j=1, n 2} \lambda_{m, j} M_{t-j}+\sum_{j=1, n 3} \lambda_{y, j} Y_{t-j}+\sum_{j=1, n 4} \lambda_{t b, j} T B_{t-j}+\sum_{j=1, n 5} \lambda_{\pi j} \pi_{t-j}+d \theta_{t}
$$

where $\mathrm{IR}_{t}$ stands for the interest rate, $M_{t}$ the money supply, $Y_{t}$ the level of industrial production, $\mathrm{TB}_{t}$ net exports and $\pi_{t}$ the rate of inflation at time period $t$. The residual term $\mathrm{d} \theta_{t}$ thus represents, the unanticipated change in exchange rate at time period $t^{5}$ The implicit assumption made by Gao $(2000)$ is that such a fundamentals-based exchange rate model is not only able to explain exchange rate movements but also able to capture market participants' expectations concerning these currency movements. Many empirical studies have however pointed out that fundamental variables such as international payment situations, money supplies, interest rates, output levels and inflation rates can hardly explain exchange rate fluctuations or market participants' behavior (Frankel and Rose, 1995).

One of the reasons why the vast majority of foreign exchange risk exposure studies use realized changes in spot exchange rates as a proxy for unexpected currency movements is that it may be difficult to estimate to what extent realized currency fluctuations have been anticipated. While forward

\footnotetext{
2 Including the stock market return in equation (1) dramatically reduces the residual variances of the regression. In addition, the market return implicitly controls for the value-relevant macroeconomic factors that are correlated with the exchange rates. As was suggested by Bodnar and Wong (2003) this measurement of the firm exposure estimate improves (somewhat) the precision of the exposure elasticity estimates, but more importantly, improves the interpretation of a firm having zero firmspecific exposure. The empirical result of having zero exposure no longer implies that the firm's value is independent of exchange rates; rather, a zero firm-specific exposure implies that the firm value is affected to the same degree as the market portfolio.

${ }^{3}$ See for instance Jorion (1990), Bodnar and Gentry (1993), Bartov and Bodnar (1994), He and Ng (1998).

4 See for instance and Gao (2000).

5 Investigating the impact of these unanticipated exchange rate changes $d \theta_{t}$ on a sample of 80 multinational firms (Eq. 2), Gao (2000) shows that they have stronger effects on firm value than the original exchange rate variation series.
} 
exchange rate data are available since the mid 90s, surprisingly the literature did not investigate yet in how far the market's consensus forecasts as reflected in forward markets affect investors' assessment of firms' exchange rate exposure. Several reasons induce us to use as well exchange rate expectations surveys in addition to forward rates when measuring 'unanticipated' currency movements. The first is that tests of bias in the forward market show a persistent pattern whereby the exchange rate not only on average fails to move in line with the predictions of the forward discount or interest differential, but actually moves in the opposite direction. In other words, relatively high domestic nominal interest rates predict an appreciation of the domestic currency. This empirical finding and its implications for returns on international currency deposits are referred to as the "forward premium puzzle". ${ }^{6}$ A second reason to prefer these surveys is that they free us from imposing the restriction that investors made no systematic prediction errors in the sample; a proposition that we would like to be able to test empirically rather than impose. Such systematic errors could occur because of a failure of the rational expectations methodology, or because important events which affect expectations did not happen a representative number of times in the sample (the "peso problem"). The use of survey data is a way of addressing the problem that agents form their expectations on the basis of a far wider set of expectations formation. Additionally given that a number of theoretical arguments have been developed to establish that the forward exchange rate is a biased predictor of futures spot exchange rates, it is possible that investors feel reluctant to reflect anticipations based on forward markets in their stock valuation process. While survey-based exchange rate expectations have been shown to have nonnegligible predictive power, they most of all have the advantage that they translate market participants' sentiment about the future path of currency fluctuations and may hence constitute valuable information for investors. Today, the survey data has become a standard basis from which to measure the unanticipated component of exchange rate changes.

This paper is yet another effort to provide empirical evidence on the sensitivity of the value of U.S. multinational firms to exchange rate news by exploiting survey-based market participants' expectations. Unlike most previous studies of exchange rate exposure, we explicitly consider innovations in exchange rate movements by taking into account the short- and long-term expectations as they are formed on forward markets and among panelists. The extent to which a firm exposes itself to exchange rate news depends on many aspects of both the firm and market participants' behavior. But there is no doubt that the extent to which exchange rates change by more or less than had been expected by market participants affects firm value because investors and managers use these publicly disclosed forecasts in their pricing and hedging decisions.

\section{Sample selection of U.S. multinational firms and survey-based expectations}

\subsection{U.S. multinational firms}

We begin by describing the selection of U.S. multinational firms with real operations in foreign countries. The focus on multinational companies allows us to concentrate on firms that, due to their real foreign trade and production activities, are expected to be affected by exchange rate shocks. ${ }^{7}$ The selection procedure of these firms consists of three steps. The first selection step identifies all U.S. companies registered in the 15th edition of the Directory of American Firms Operating in Foreign Countries. As only listed firms are included in our study, we check the firms for their daily stock market return availability in the University of Chicago Center for Research in Security Prices (CRSP) database.

\footnotetext{
${ }^{6}$ The rejection of forward market efficiency may be attributable to the irrationality of market participants, to the existence of time-varying risk premia, learning about a policy change, or to some combination of these phenomena (Cavaglia et al., 1993, 1994; Engel, 1996).

${ }^{7}$ Firms whose sales and sourcing are totally limited to the domestic market may also be exposed to shifts in the competitive environment caused by changes in foreign exchange rates. As the exposure of domestic firms is primarily operating exposure which occurs because current, and particularly, future profits from operations depend on exchange rates - and, more importantly, as investors may be less aware of the operating exposure of domestic firms, some authors argue that it may take, on average, more time to detect the impact of currency movements on domestic companies in comparison with multinational firms (Bartov and Bodnar, 1994).
} 
Table 1

Market capitalization, debt structure and foreign sales of U.S. multinational sample firms.

This table presents descriptive statistics for the market value, debt structure and foreign sales of the 634 companies included in our sample. For each company, the market capitalization, debt ratio and foreign sales ratio have been calculated as the average value over the entire sample period.

\begin{tabular}{llrrrr}
\hline & $N$ & Mean & First quartile & Median & Third quartile \\
\hline Market capitalization & 634 & $64,556,947$ & 332,611 & $1,086,295$ & $7,945,734$ \\
Debt/equity ratio & 589 & $181.77 \%$ & $53.96 \%$ & $121.59 \%$ & $263.15 \%$ \\
Foreign sales/total sales & 511 & $47.33 \%$ & $35.91 \%$ & $51.85 \%$ & $69.23 \%$ \\
\hline
\end{tabular}

Market capitalizations are in thousands of U.S. dollars. For some companies the debt/equity ratio, and the foreign sales/total sales ratio, is not made available by the Datastream International database. $N$ shows the numbers of observations.

Companies are further required to provide at least five years of consecutive daily returns across the entire sample period from March, 12th 1999 till December, 31st 2009. The entire procedure yields a sample of 634 U.S. multinational firms. For all these companies, the data employed are daily adjusted prices obtained from CRSP and Datastream International from March, 12th 1999 till December, 31st 2009. The use of daily prices is essential in order to extract for each company in each month the share price on that particular day on which the expectations for the various exchange rates are formed. ${ }^{8}$

Table 1 gives a brief overview on the size, debt structure and foreign sales activities of the firms included in our sample. The summary statistics of the market values and debt ratios clearly indicate the presence of several relatively large and strongly leveraged companies in our sample. It should furthermore be emphasized that the selected U.S. multinationals are extensively involved in international activities as their foreign sales account on average for almost $50 \%$ of their total sales. ${ }^{9}$

The foreign operations of the U.S. multinationals in our sample may be grouped in seven geographical regions: Canada, Europe, U.K., Asia, Australia, Latin America and Africa. In Table 2, we provide information about the geographical dispersion of these foreign trade and/or production activities. It is interesting to observe that the major international trading activities of the 634 U.S. multinationals included in our sample are located in Canada, Europe, U.K. and Asia. While all companies active in Africa - with one exception - seem to have trading and production relationships throughout the world, it should be stressed that on average $80 \%$ of the companies that have real operations in Asia, Australia, Latin America or Africa also have trading links in Europe and Canada. Finally, only a very few firms appear to be exclusively focused on one geographical region.

\subsection{Exchange risk factors}

The data on the unexpected exchange rate changes is obtained from two sources. On the one hand we use market determined forward exchange rates. On the other we use survey-based expectations among market participants.

Regarding the latter, every second Monday of each calendar month Consensus Economics of London publishes results from a survey among up to 150 leading professional market participants and forecasting agencies for their subjective expectations of a large number of exchange rates. Examples of panel companies are Morgan Stanley, Oxford Economic Forecasting, Deutsche Bank Research and BNP Paribas. The forecasts are point forecasts against the U.S. dollar and are available for various forecast horizons ranging from 1 month to 24 months ahead.

For our panel, we obtain the cross-sectional average expectations on the Argentine peso, Australian dollar, Brazilian real, Canadian dollar, Chilean peso, Chinese renminbi, euro, Hong Kong dollar, Japanese yen, Malaysian ringit, Mexican peso, New Zealand dollar, South African rand, Singaporean dollar, South

\footnotetext{
${ }^{8}$ The expectation formation day is usually the Friday before the second Monday of the month (see Section 3.2 for more details on the expectation series).

${ }^{9}$ As suggested in Bartov and Bodnar (1994), the focus on firms with large foreign revenues does not necessarily favor the detection of significant foreign exchange risk exposures, as these firms are more likely to hedge their foreign exposures (with financial or operational strategies) and are able to undertake these hedging activities at a lower cost.
} 


\section{Table 2}

Geographic dispersion of the foreign activities of U.S. multinational sample firms.

This table gives a brief description of the geographic dispersion of the foreign activities of the U.S. multinational companies included in our sample. $79.64 \%$ of U.S. multinational firms that have real operations in the U.K., for instance, also have real operations in Europe (ex U.K.).

\begin{tabular}{lllllllll}
\hline & $N$ & Canada & Europe & U.K. & Asia & Australia & L. America & Africa \\
\hline Canada & 441 & & $87.07 \%$ & $82.99 \%$ & $72.79 \%$ & $55.33 \%$ & $67.57 \%$ & $24.26 \%$ \\
Europe & 437 & $87.87 \%$ & & $81.46 \%$ & $72.77 \%$ & $50.57 \%$ & $53.55 \%$ & $22.65 \%$ \\
U.K. & 447 & $81.88 \%$ & $79.64 \%$ & & $74.72 \%$ & $47.20 \%$ & $51.01 \%$ & $20.36 \%$ \\
Asia & 420 & $76.43 \%$ & $75.71 \%$ & $79.52 \%$ & & $59.76 \%$ & $51.90 \%$ & $24.52 \%$ \\
Australia & 260 & $93.85 \%$ & $85.00 \%$ & $81.15 \%$ & $96.54 \%$ & & $72.69 \%$ & $35.00 \%$ \\
L. America & 312 & $95.51 \%$ & $75.00 \%$ & $73.08 \%$ & $69.87 \%$ & $60.58 \%$ & & $30.45 \%$ \\
Africa & 114 & $93.86 \%$ & $86.84 \%$ & $79.82 \%$ & $90.35 \%$ & $79.82 \%$ & $83.33 \%$ & \\
Total sample & 634 & $69.56 \%$ & $68.93 \%$ & $70.50 \%$ & $66.25 \%$ & $41.01 \%$ & $49.21 \%$ & $17.98 \%$ \\
\hline
\end{tabular}

Source: 15th edition of the Directory of American Firms Operating in Foreign Countries.

Korean won, Thai baht, Canadian dollar, and United Kingdom pound versus the U.S. dollar for the period from November 1999 through December 2009. This period is of particular interest since it contains several financial crises and several large changes in the level of some exchange rates. Specifically, for these currencies we obtain both the 1-, 3- and 12-month forward exchange rates and the consensus average expectations that are made 1,3 , and 12 months ahead. ${ }^{10,11}$

Although the survey participants have a few days time to return their expectations, we know that the vast majority send their forecasts by e-mail on the Friday before the publication day (usually second Monday of the month). We consider this Friday to be the day on which the expectations are formed. On this Friday, we also obtain spot as well as 1-, 3- and 12-month forward exchange rate data to match the survey data. All spot and forward-rate series are obtained through Datastream and have their origin either in Reuters or Barclays Bank International. ${ }^{12}$

Typical concerns when using survey data in any setting are whether this data reflects the true market expectations, whether the expectations are biased because of strategic behavior from the panelists, or whether forecasts from surveys are any good in an out-of-sample forecast setting a criteria that has often been put forward to evaluate the quality of survey expectations. It should be noted that for survey data in the present setting it is most important that the survey expectations reflect the market sentiment at the time they are formed, that is, the survey data should reflect expectations only, and nothing else. While it is not the primary concern that the expectations outperform other forecasting techniques, there is general consensus that expectations from surveys in general perform no worse than any other forecast technique. In addition, we can learn much about the usefulness of survey measures of expectations from related fields. Ang et al. (2007) for instance, provide recent evidence that aggregate expectations from various surveys on inflation consistently deliver better forecasts than time-series models, models based on the yield curve, and forecasts based on the Phillips curve, which highlights the usefulness of survey measures of expectations. Elliott and Ito (1999) find that in the foreign exchange market portfolio strategies based on survey expectations produce small, but positive, profits.

We proceed by defining the natural logarithm of the current spot rate on a particular currency $j$ at time $t$ as $s_{j, t}$ and the natural logarithm of the $k$-period ahead forward-rate-based expectation or survey-

\footnotetext{
${ }^{10}$ We excluded 24-month-ahead expectations as this would considerably reduce the number of observations in our total sample period 1999-2009.

11 We use consensus measures of expectations as they are likely to perform better than the individual expectations that together make the consensus. Although some individuals' forecast performance may be better than others' - in terms of criteria like root mean squared errors - it is difficult to identify a priori who these individuals are, in particular since forecast performance is generally not constant over time. As surveys aggregate the expectations from many market participants, the information in consensus measures is thus usually superior, which may be due to an effect similar to the Bayesian model averaging or to the fact that the common components of the forecasts are implicitly filtered out in the consensus value.

12 To verify that the information sets of market participants are not too diverse, all of the analyses throughout this study were re-estimated using spot data from various days surrounding this Friday, yet the overall results remained virtually unchanged.
} 
based consensus expectation formed at time $t$ for delivery at time $t+k$ as $s_{j, t, t+k}^{\mathrm{e}}$ and make the assumption that both types of expectations correspond to the unobserved 'true' market observation up to a white noise random error, so that $s_{j, t, t+k}^{\mathrm{e}}=E_{t}\left[s_{j, t+k}\right]+\varepsilon_{j, t+k}$. The $k$-period realized change in the exchange rate can hence be decomposed into an 'anticipated' (or expected) component and an 'unanticipated' (or noise) component ${ }^{13}$ :

$$
s_{j, t+k}-s_{j, t}=\left(s_{j, t, t+k}^{e}-s_{j, t}\right)+\left(s_{j, t+k}-s_{j, t, t+k}^{e}\right)
$$

The expectations for the individual currencies are grouped together to construct seven region-specific indices. The indices are region-specific trade-weighted exchange rate indices ${ }^{14}$ that translate the evolution of one or more foreign currencies of the same geographical region into the U.S. dollar. They are computed as a weighted average of 'realized' - respectively 'unexpected' - bilateral exchange rates according to the following formula:

$$
X_{t}=\sum_{1, n}\left(\left(\exp _{k}+i m p_{k}\right) /\left(\sum_{1, n}\left(\exp _{k}+i m p_{k}\right)\right) * X_{k t}\right)
$$

where $n$ is the number of countries included in the region, $\exp _{k}$ is the export flow from the U.S. toward country $k, \mathrm{imp}_{k}$ the import flow from country $k$ toward the U.S. and $X_{k t}$ the bilateral 'realized' respectively 'unexpected' - exchange rate change between the U.S. dollar and country $k$ 's currency. The weights of the region-specific indices, updated monthly, are based on each country's proportion of trade in the total import and export flows of the entire region with the U.S. $-\sum_{1, n}\left(\exp _{k}+\operatorname{imp}_{k}\right)-$ as
reported by the Foreign Trade Division of the U.S. Census Bureau.

Table 3 provides summary statistics of these region-specific indices. Since all series are in natural logarithms, we can interpret the figures as percentage changes. Several consistencies emerge. First of all, at the 1- and 3-month forecast horizons, the standard deviations of the unexpected exchange rate changes are generally larger than the realized change. This is particularly the case for the unexpected survey-based forecasted change. This implies that the role of currency changes in previous exposure literature that focuses on realized changes is potentially understated. In addition, if unexpected changes are larger and more volatile than actual changes, market participants underestimated most of the change or even missed the direction of the exchange rate change, and hence most of the change comes at a surprise for investors. At the 12-month forecast horizon, there is no apparent difference anymore between the realized and unexpected changes anymore.

Second, at the 1-month forecast horizon the unexpected survey-based change has the opposite sign as compared to the realized change for 5 of the 6 currencies (or currency indexes), implying that the expected survey-based change has the same sign as the realized change. The survey-based exchange rate forecasts are therefore better able to forecast the actual change at the shorter forecast horizon than the forward-rate-based expected change. At the 3-month forecast horizon these differences diminish and at the 12-month horizon the forward-rate-based expectations are better able to predict the proper exchange rate change, an indication that fundamentals (as incorporated in the forward-rate) gain predictive power.

Third, at the 1-month forecast horizon, most changes are skewed to the right, which indicates that there are some large appreciations in the currencies during the sample period. In addition, there is strong evidence of positive excess kurtosis, which indicates that the distribution is fat tailed. Very large changes from the previous period therefore occur fairly often. When the forecast horizon lengthens to 3 and 12 months ahead, there is no clear sign of positive or negative skewness anymore. While there is still evidence of positive excess kurtosis at the 3-month forecast horizon, this also disappears at the 12-month horizon, where there is no apparent evidence of lepto- or platykurtosis anymore. For all of the forecast horizons there is no apparent difference in skewness or kurtosis between the realized change, unexpected forward-rate-based change and unexpected survey-based change.

\footnotetext{
${ }^{13}$ For simplicity, we will denote the unanticipated exchange rate change as $d \theta_{t, t+k}$ in the remainder of this paper.

14 Following Jorion (1990) and Dominguez and Tesar (2001a, b), exchange rate indices are parsimonious representations of the effect of multiple exchange rate changes.
} 
Table 3

Summary statistics of realized versus unexpected exchange rate movements.

The table reports summary statistics for the realized and unexpected (both using forward rates and survey forecasts) 1-, 3-, and 12-month log price changes for the period of January 1999-December 2008. All changes are in percentages and are annualized, as to allow for a better comparison.

\begin{tabular}{|c|c|c|c|c|c|c|c|c|c|}
\hline & & Mean & Median & Std. Dev. & Skewness & Kurtosis & Jarque-Bera & Prob. & Obs. \\
\hline \multicolumn{10}{|c|}{ 1-Month forecast horizon } \\
\hline \multirow[t]{6}{*}{ Realized } & Asian index & $-1.52 \%$ & $-0.55 \%$ & $4.85 \%$ & 0.20 & 3.08 & 0.86 & 0.6491 & 120 \\
\hline & Australian index & $-1.37 \%$ & $1.03 \%$ & $11.58 \%$ & 0.47 & 4.59 & 17.08 & 0.0002 & 120 \\
\hline & Euro & $1.64 \%$ & $-1.56 \%$ & $10.76 \%$ & 0.06 & 2.69 & 0.53 & 0.7663 & 120 \\
\hline & Latin American index & $3.11 \%$ & $-3.01 \%$ & $9.36 \%$ & 2.03 & 13.55 & 639.15 & 0.0000 & 120 \\
\hline & South African rand & $5.36 \%$ & $5.52 \%$ & $17.29 \%$ & 0.42 & 3.65 & 5.57 & 0.0617 & 120 \\
\hline & U.K. pound & $-0.61 \%$ & $0.18 \%$ & $9.97 \%$ & -0.79 & 6.69 & 80.59 & 0.0000 & 120 \\
\hline \multirow[t]{6}{*}{ Unexp. forw. } & Asian index & $0.70 \%$ & $0.38 \%$ & $4.60 \%$ & 0.05 & 2.76 & 0.34 & 0.8454 & 120 \\
\hline & Australian index & $-3.44 \%$ & $-0.56 \%$ & $11.59 \%$ & 0.43 & 4.39 & 13.32 & 0.0013 & 120 \\
\hline & Euro & $1.35 \%$ & $-1.20 \%$ & $10.88 \%$ & 0.05 & 2.64 & 0.69 & 0.7072 & 120 \\
\hline & Latin American index & $-5.14 \%$ & $-8.33 \%$ & $8.89 \%$ & 2.37 & 16.80 & 1064.73 & 0.0000 & 120 \\
\hline & South African rand & $-16.23 \%$ & $-5.76 \%$ & $22.48 \%$ & -0.43 & 3.76 & 6.68 & 0.0354 & 120 \\
\hline & U.K. pound & $0.49 \%$ & $0.66 \%$ & $9.99 \%$ & -0.78 & 6.71 & 80.91 & 0.0000 & 120 \\
\hline \multirow[t]{6}{*}{ Unexp. surv. } & Asian index & $3.23 \%$ & $2.39 \%$ & $5.15 \%$ & 0.19 & 3.79 & 3.81 & 0.1490 & 120 \\
\hline & Australian index & $10.93 \%$ & $2.20 \%$ & $15.64 \%$ & 0.71 & 3.66 & 12.29 & 0.0021 & 120 \\
\hline & Euro & $-4.75 \%$ & $-6.18 \%$ & $12.37 \%$ & -0.10 & 2.49 & 1.48 & 0.4760 & 120 \\
\hline & Latin American index & $-5.38 \%$ & $-12.23 \%$ & $11.75 \%$ & 2.39 & 13.91 & 709.33 & 0.0000 & 120 \\
\hline & South African rand & $0.29 \%$ & $2.52 \%$ & $20.37 \%$ & 0.27 & 4.01 & 6.60 & 0.0369 & 120 \\
\hline & U.K. pound & $-1.59 \%$ & $-2.10 \%$ & $10.56 \%$ & -1.01 & 8.02 & 146.37 & 0.0000 & 120 \\
\hline \multicolumn{10}{|c|}{ 3-Month forecast horizon } \\
\hline \multirow[t]{6}{*}{ Realized } & Asian index & $-1.55 \%$ & $-0.85 \%$ & $4.33 \%$ & -0.06 & 3.43 & 0.99 & 0.6093 & 120 \\
\hline & Australian index & $-0.18 \%$ & $-3.28 \%$ & $13.67 \%$ & 1.79 & 8.86 & 235.38 & 0.0000 & 120 \\
\hline & Euro & $0.78 \%$ & $2.66 \%$ & $11.02 \%$ & -0.49 & 3.34 & 5.33 & 0.0696 & 120 \\
\hline & Latin American index & $3.84 \%$ & $-0.17 \%$ & $10.15 \%$ & 2.56 & 13.16 & 646.75 & 0.0000 & 120 \\
\hline & South African rand & $7.11 \%$ & $5.58 \%$ & $17.90 \%$ & 0.35 & 3.75 & 5.27 & 0.0716 & 120 \\
\hline & U.K. pound & $-0.67 \%$ & $0.66 \%$ & $9.66 \%$ & -1.33 & 8.63 & 194.13 & 0.0000 & 120 \\
\hline \multirow[t]{6}{*}{ Unexp. forw. } & Asian index & $0.82 \%$ & $1.09 \%$ & $4.11 \%$ & -0.44 & 3.45 & 4.83 & 0.0893 & 120 \\
\hline & Australian index & $-2.34 \%$ & $-5.74 \%$ & $13.60 \%$ & 1.65 & 8.36 & 197.63 & 0.0000 & 120 \\
\hline & Euro & $0.82 \%$ & $1.72 \%$ & $11.19 \%$ & -0.43 & 3.15 & 3.80 & 0.1496 & 120 \\
\hline & Latin American index & $-4.08 \%$ & $-8.53 \%$ & $10.42 \%$ & 2.49 & 12.84 & 608.16 & 0.0000 & 120 \\
\hline & South African rand & $-13.27 \%$ & $-1.40 \%$ & $27.71 \%$ & -0.84 & 3.71 & 16.55 & 0.0003 & 120 \\
\hline & U.K. pound & $0.52 \%$ & $0.98 \%$ & $9.66 \%$ & -1.21 & 8.23 & 166.36 & 0.0000 & 120 \\
\hline \multirow[t]{6}{*}{ Unexp. surv. } & Asian index & $-0.10 \%$ & $0.81 \%$ & $4.58 \%$ & -0.21 & 3.44 & 1.87 & 0.3916 & 120 \\
\hline & Australian index & $3.59 \%$ & $0.10 \%$ & $14.89 \%$ & 1.47 & 6.49 & 104.17 & 0.0000 & 120 \\
\hline & Euro & $-1.29 \%$ & $0.04 \%$ & $11.70 \%$ & -0.42 & 3.18 & 3.75 & 0.1534 & 120 \\
\hline & Latin American index & $0.24 \%$ & $-5.09 \%$ & $10.61 \%$ & 2.72 & 14.21 & 776.62 & 0.0000 & 120 \\
\hline & South African rand & $4.74 \%$ & $4.06 \%$ & $19.01 \%$ & 0.32 & 3.76 & 4.96 & 0.0837 & 120 \\
\hline & U.K. pound & $-0.86 \%$ & $0.56 \%$ & $9.78 \%$ & -1.53 & 9.85 & 281.73 & 0.0000 & 120 \\
\hline \multicolumn{10}{|c|}{ 12-Month forecast horizon } \\
\hline \multirow[t]{6}{*}{ Realized } & Asian index & $-2.16 \%$ & $-2.49 \%$ & $4.57 \%$ & 0.42 & 3.11 & 3.61 & 0.1642 & 120 \\
\hline & Australian index & $-4.87 \%$ & $-6.66 \%$ & $22.84 \%$ & 0.36 & 2.76 & 2.91 & 0.2333 & 120 \\
\hline & Euro & $2.64 \%$ & $3.82 \%$ & $10.64 \%$ & -0.21 & 2.16 & 4.40 & 0.1107 & 120 \\
\hline & Latin American index & $2.46 \%$ & $1.31 \%$ & $7.53 \%$ & 0.80 & 3.19 & 12.91 & 0.0016 & 120 \\
\hline & South African rand & $4.33 \%$ & $7.63 \%$ & $18.94 \%$ & -0.40 & 2.79 & 3.48 & 0.1757 & 120 \\
\hline & U.K. pound & $1.03 \%$ & $1.35 \%$ & $8.70 \%$ & -1.00 & 5.19 & 43.81 & 0.0000 & 120 \\
\hline \multirow[t]{6}{*}{ Unexp. forw. } & Asian index & $0.27 \%$ & $-0.16 \%$ & $4.16 \%$ & 0.36 & 2.74 & 2.87 & 0.2384 & 120 \\
\hline & Australian index & $-4.31 \%$ & $-6.11 \%$ & $12.91 \%$ & 0.33 & 2.83 & 2.32 & 0.3130 & 120 \\
\hline & Euro & $2.73 \%$ & $4.11 \%$ & $11.59 \%$ & -0.30 & 2.29 & 3.94 & 0.1392 & 120 \\
\hline & Latin American index & $-3.68 \%$ & $-4.11 \%$ & $10.81 \%$ & 0.39 & 4.26 & 10.98 & 0.0041 & 120 \\
\hline & South African rand & $-9.67 \%$ & $3.01 \%$ & $33.33 \%$ & -1.15 & 3.42 & 27.28 & 0.0000 & 120 \\
\hline & U.K. pound & $2.08 \%$ & $2.49 \%$ & $9.02 \%$ & -0.87 & 4.63 & 28.43 & 0.0000 & 120 \\
\hline
\end{tabular}


Table 3 (continued)

\begin{tabular}{|c|c|c|c|c|c|c|c|c|c|}
\hline & & Mean & Median & Std. Dev. & Skewness & Kurtosis & Jarque-Bera & Prob. & Obs. \\
\hline \multirow[t]{6}{*}{ Unexp. surv. } & Asian index & $-1.93 \%$ & $-2.15 \%$ & $4.61 \%$ & 0.39 & 3.18 & 3.20 & 0.2019 & 120 \\
\hline & Australian index & $-1.69 \%$ & $-4.09 \%$ & $12.60 \%$ & 0.50 & 2.95 & 4.92 & 0.0856 & 120 \\
\hline & Euro & $2.14 \%$ & $3.44 \%$ & $10.90 \%$ & -0.19 & 2.21 & 3.83 & 0.1473 & 120 \\
\hline & Latin American index & $1.57 \%$ & $-0.33 \%$ & $7.41 \%$ & 0.83 & 3.17 & 13.96 & 0.0009 & 120 \\
\hline & South African rand & $3.72 \%$ & $5.60 \%$ & $19.41 \%$ & -0.39 & 2.71 & 3.55 & 0.1697 & 120 \\
\hline & U.K. pound & $1.04 \%$ & $0.42 \%$ & $8.72 \%$ & -0.95 & 5.02 & 38.54 & 0.0000 & 120 \\
\hline
\end{tabular}

\section{Methodology}

Following the extensive literature on foreign exchange rate exposure we measure the firm-specific exchange rate sensitivity, called firm-specific exposure, as the effect of exchange rate changes on the value of a firm in excess of the global market's reaction to foreign exchange rate movements ${ }^{15}$ :

$$
R_{i, t, t+k}=\alpha_{i}+\beta_{i} R_{m, t, t+k}+\gamma_{i} \theta_{t, t+k}+\varepsilon_{i, t, t+k}
$$

where $R_{i, t, t+k}$ designates the total return of firm $i$ over the period $t$ until $t+k, R_{m, t, t+k}$ the global stock market return over the period $t$ until $t+k, \beta_{i}$ firm i's return sensitivity to market fluctuations, $\theta_{t, t+k}$ the change in the exchange risk factor from period $t$ until $t+k$ (measured as the U.S. dollar price of the foreign currency), $\gamma_{i}$ firm $i$ 's exposure to exchange rate changes independent of the effect these variations have on the overall market, and $\varepsilon_{i, t, t+k}$ denotes the white noise error term. The proxy for the market portfolio used in this study is the CRSP value-weighted U.S. market index as provided by the CRSP database.

Hence $\gamma_{i}$ is the exchange rate exposure measure because it describes the sensitivity of stock returns to unanticipated changes in exchange rates. An appreciation of the U.S. dollar makes exporting goods more expensive in terms of foreign currencies, and this may lead to a fall in foreign demand and foreign sales revenue. On the other hand, the importing firm will benefit from an appreciation of the U.S. dollar, as its imports become cheaper in terms of the domestic currency. Thus, the $\gamma_{i}$ coefficient should be positive for net exporters and negative for net importers. ${ }^{16}$ Furthermore, changes in exchange rates alter the domestic-currency value of foreign currency-denominated fixed assets and liabilities; U.S. multinational firms with net exposed foreign-denominated liabilities will gain from a strengthening domestic currency, while firms with net exposed foreign-denominated assets lose.

Jorion's residual firm-specific exposure to exchange rate changes should be interpreted with due care (Muller and Verschoor, 2006c). A difficulty with using Jorion's augmented market model is the definition of the exchange risk factor. ${ }^{17}$ The use of trade-weighted baskets of currencies may lack power if a firm is mostly exposed to only a few currencies within the basket (Williamson, 2001). Employing alternatively a trade-weighted exchange rate index and bilateral rates, Dominguez and Tesar (2001b) demonstrate that, since trade-weights do not correspond with individual firms' or industries' trade patterns, the use of trade-weighted exchange rate indices leads to underestimation of the impact of exchange rate shocks. ${ }^{18}$ Thus, the relevance of currencies should be a function of the firm-specific strategic position. In his study of the mining sector of Australia, Khoo (1994) therefore, examines for each subgroup of firms the relative importance of their trading partners and selects the currency exchange rates to be taken into account accordingly. Similarly, Ihrig (2001) builds firm-specific

\footnotetext{
15 See, for instance Adler and Dumas (1984) and Jorion (1990).

16 Note that the sign of the exchange rate exposure coefficient becomes less distinct for a company engages in both imports and exports. See, for example, Adler and Dumas (1984) and $\mathrm{He}$ and $\mathrm{Ng}$ (1998) for their suggestion that the sensitivity of the firm value to exchange rate fluctuations depends on the elasticity of the firm's demand for foreign goods relative to the elasticity of the foreign market's demand for the firm's goods.

17 Dominguez and Tesar (2001a) and Fraser and Pantzalis (2004) empirically describe how the choice of the index used to capture exposure influences the level of exposures observed.

18 Dominguez and Tesar (2001b) show that many firms are exposed to one or more bilateral currency rates whereas they are not exposed to the index.
} 
exchange rate indices that are composed of bilateral rates of all countries in which the companies have subsidiaries and finds more significant exposures with the firm-specific index than earlier exposure studies. In this paper, we therefore disaggregate the common trade-weighted exchange rate index into six region-specific trade-weighted indices based on each individual firm's trading or production links with one of the seven following regions: Canada, Europe, U.K., Asia, Australia, Latin America and Africa:

$$
R_{i, t, t+k}=\alpha_{i}+\beta_{i} R_{m, t, t+k}+\gamma_{i} \theta_{t, t+k}+\varepsilon_{i, t, t+k}
$$

with

$$
\begin{aligned}
\gamma_{i} \theta_{t, t+k}= & \gamma_{C A, i} \theta_{C A, t, t+k} * D_{C A, i}+\gamma_{E U, i} \theta_{E U, t, t+k} * D_{E U, i}+\gamma_{U K, i} \theta_{U K, t, t+k} * D_{U K, i}+\gamma_{A S, i} \theta_{A S, t+k, t} * D_{A S, i} \\
& +\gamma_{A U, i} \theta_{A U, t, t+k} * D_{A U, i}+\gamma_{L A, i} \theta_{L A, t, t+k} * D_{L A, i}+\gamma_{S A, i} \theta_{S A, t, t+k} * D_{S A, i}
\end{aligned}
$$

$\theta_{\mathrm{CA}, t, t+k}, \theta_{\mathrm{EU}, t, t+k}, \theta_{\mathrm{UK}, t, t+k}, \theta_{\mathrm{AS}, t, t+k}, \theta_{\mathrm{AU}, t, t+k}, \theta_{\mathrm{LA}, t, t+k}, \theta_{\mathrm{SA}, t, t+k}$ denote the fluctuation of the price of one Canadian dollar, euro, U.K. pound, basket of Asian currencies, Australian dollar, basket of Latin American currencies and South African rand in terms of U.S. dollars over the period $t$ until $t+k$. $D_{\mathrm{CA}, i}, D_{\mathrm{EU}, i}$, $D_{\mathrm{UK}, i}, D_{\mathrm{AS}, i}, D_{\mathrm{AU}, i}, D_{\mathrm{LA}, i}, D_{\mathrm{SA}, i}$ describe the presence of firm $i$ 's real activities in Canada, Europe, the U.K., Asia, Australia, Latin America and South Africa. Depending on the presence or absence of firm i's real activities in region $j$, the dummy variable $D_{j, i}$ takes the value of 1 or 0 . Finally, $\gamma_{\mathrm{CA}, i}, \gamma_{\mathrm{EU}, i}, \gamma_{\mathrm{UK}, i}, \gamma_{\mathrm{AS}, i}, \gamma_{\mathrm{AU}, i}$, $\gamma_{\mathrm{LA}, i}, \gamma_{\mathrm{SA}, i}$ measure firm $i$ 's exchange risk exposure to the Candian dollar, euro, the U.K. pound, Asian currencies, the Australian dollar, Latin American currencies and the South African rand.

As outlined in Section 2, a crucial question regarding the estimation of foreign exchange risk exposure is the specification of 'unanticipated' exchange rate movements. In contrast to the vast majority of previous empirical studies that use changes in realized spot exchange rates as a proxy for 'unanticipated' currency movements, we adopt a new empirical specification and define the 'unanticipated' part of the exchange rate movement as the difference between the 'realized' exchange rate movement and either the 1-, 3- or 12-month forward exchange rate or the consensus average 1-, 3- or 12-month expectation of foreign exchange market participants. The complete econometric model hence becomes:

$$
R_{i, t, t+k}=\alpha_{i}+\beta_{i} R_{m, t, t+k}+\gamma_{i}^{\prime} d \theta_{t, t+k}+\varepsilon_{i, t, t+k}
$$

with

and

$$
\begin{aligned}
\gamma_{i}^{\prime} d \theta_{t, t+k}= & \gamma_{C A, i}^{\prime} d \theta_{C A, t, t+k} * D_{C A, i}+\gamma_{E U, i}^{\prime} d \theta_{E U, t, t+k} * D_{E U, i}+\gamma_{U K, i}^{\prime} d \theta_{U K, t, t+k} * D_{U K, i}+\gamma_{A S, i}^{\prime} d \theta_{A S, t, t+k} \\
& * D_{A S, i}+\gamma_{A U, i}^{\prime} d \theta_{A U, t, t+k} * D_{A U, i}+\gamma_{L A, i}^{\prime} d \theta_{L A, t, t+k} * D_{L A, i}+\gamma_{S A, i}^{\prime} d \theta_{S A, t, t+k} * D_{S A, i}
\end{aligned}
$$

$$
d \theta_{r e g(k), t, t+k}=\theta_{\operatorname{reg}(k), t, t+k}-E\left(\theta_{\operatorname{reg}(k), t, t+k}\right)
$$

where

$$
\operatorname{reg}(k)=\text { Canada, Europe, U.K., Asia, Australia, Latin America, respectively South Africa }
$$

$\mathrm{d} \theta_{\mathrm{CA}, t, t+k}, \mathrm{~d} \theta_{\mathrm{EU}, t, t+k}, \mathrm{~d} \theta_{\mathrm{UK}, t, t+k}, \mathrm{~d} \theta_{\mathrm{AS}, t, t+k}, \mathrm{~d} \theta_{\mathrm{AU}, t, t+k}, \mathrm{~d} \theta_{\mathrm{LA}, t, t+k}, \mathrm{~d} \theta_{\mathrm{SA}, t, t+k}$ measure the 'unanticipated' - as defined in Section 3.2 - fluctuation of the price of one Candadian dollar, euro, U.K. pound, basket of Asian currencies, Australian dollar, basket of Latin American currencies and South African rand in U.S. dollars terms over the period $t$ until $t+k$; and $\gamma_{\mathrm{CA}, i}^{\prime}, \gamma_{\mathrm{EU}, i,}^{\prime}, \gamma_{\mathrm{UK}, i}^{\prime}, \gamma_{\mathrm{AS}, i}^{\prime}, \gamma_{\mathrm{AU}, i}^{\prime}, \gamma_{\mathrm{LA}, i}^{\prime}, \gamma_{\mathrm{SA}, i}^{\prime}$ stand for firm $i$ 's sensitivity toward 'unexpected' movements in the value of the Canadian dollar, euro, the U.K. pound, Asian currencies, the Australian dollar, Latin American currencies and the South African rand. ${ }^{19}$

\footnotetext{
19 To be able to compare the results of Eq. (6) and Eq. (7), it should be stressed that the series of both the 'realized' exchange rate movements - used in Eq. (6) - and the stock returns have been constructed based on daily databases (of spot exchange rates and adjusted stock prices, respectively) in order to exactly match the dates of formation and maturities of the exchange rate expectation data.
} 
Finally, it should be mentioned that the assumption of constant variance made in the aforementioned models may be violated in some cases - thus invalidating the test statistics of the ordinary least squares regression. We therefore test the residuals $\varepsilon_{i, t, t+k}$ of the models Eqs. (6) and (7) for the presence of time-varying heteroscedasticity using the test Engle derived from the Lagrange multiplier principle. If we do not reject the null hypothesis that the residuals $\varepsilon_{i, t, t+k}$ present no heteroscedasticity, we estimate the afore-mentioned models using ordinary least squares. Otherwise a GARCH(1,1) specification is added to the initial models (Eqs. (6) and (7)) and all the parameters are estimated using maximum likelihood and generated by the Berndt et al. (1974) algorithm (Bollerslev et al., 1992):

$$
\varepsilon_{i, t, t+k}=\mu_{i, t, t+k} *\left(h_{i, t, t+k}\right)^{1 / 2} \text { with } h_{i, t, t+k}=\delta_{i}+\tau_{i} \varepsilon_{i, t-k, t}^{2}+\nu_{i} h_{i, t-k, t}
$$

where $h_{i, t, t+k}$ denotes the conditional variance of the residuals over the period $t$ until $t+k ; \delta_{i}$, $\tau_{i}$ and $\nu_{i}$ unknown parameters; and $\mu_{i, t, t+k}$ represents the white noise error term. ${ }^{20}$

\section{Empirical findings}

Table 4 presents the parameter estimates of the augmented market model described in Eq. (6). In line with Muller and Verschoor (2006b), the results show that the disaggregation of the worldwide trade-weighted exchange rate index into six region-specific trade-weighted currency indices improves the detection and estimation of foreign exchange risk exposures. ${ }^{21}$ By comparison with Jorion (1990), who finds that only 5\% of 287 U.S. multinational corporations exhibit significant exchange risk exposure, and Choi and Prasad (1995) who find that 15\% of 409 multinationals are significantly exposed, our 1-month horizon estimation of foreign exposure reveals that more than $33 \%$ of the 634 U.S. multinationals included in our sample are significantly affected by currency fluctuations. Concurrently we observe an average increase in the adjusted $R^{2}$ (a measure of goodness of fit) of approximately 5\% between the estimation of Eq. (5) and the estimation of Eq. (6). Our findings thus confirm that the estimation using an aggregated trade-weighted basket of currencies (Eq. (5)) lacks power if a firm's currency exposure does not correspond to the relative weights included in the standard tradeweighted currency index (Williamson, 2001; Dominguez and Tesar, 2001b; Ihrig, 2001). As a consequence the estimation leads to a downward bias in the measurement of exposure.

Table 4 presents, furthermore, the distribution of firm- and region-specific exposure coefficients for 3- and 12-month measurement intervals. Consistent with Chow et al. (1997a,b) and Muller and Verschoor (2006a), our findings show that there is a general increase in the number of significant positive and negative exposure coefficients when lengthening the return horizon. The number of significantly exposed U.S. multinationals increases from 209 for the 1-month horizon, to 241 for the 3-month horizon and to 431 , corresponding to almost $70 \%$ of the total sample, for the 12 -month horizon. Two arguments may explain why it seems statistically and economically more difficult to identify the relationship in the short run:

(a) Given that exchange rate exposure coefficients are measured ex post - after the implementation of managers' hedging strategies (to protect the company again currency fluctuations) the difference between long- and short-run sensitivity to exchange rate movements may be induced by the fact that financial managers do hedge their short-term exposure while they are unable to properly hedge long-term economic currency exposure. Long-run exposure is unrelated to known transactions and has been shown to be very difficult to hedge (Döhring, 2008).

(b) The second explanation put forward by Bartov and Bodnar (1994) suggests that investors tend to make systematic errors when characterizing the impact of exchange rate movements on firm value. Many parameters like price elasticity, trade and production constraints, pass-through effects, industry concentration factors as well as direct and indirect internationalization have

\footnotetext{
20 The $\delta_{i}, \tau_{i}$ and $\nu_{i}$ parameter estimates are not shown in Tables 3-5 but are available from the authors upon request.

21 Estimation results of Eq. (5) using a standard trade-weighted exchange rate index to measure firms' sensitivity to aggregate currency fluctuations are available from the authors upon request.
} 


\section{Table 4}

U.S. multinationals' foreign exchange risk exposure to realized exchange rate movements.

This table presents, for $k=1,3$ and 12 months, cross-sectional summary statistics of the estimation of the following regression model:

$$
\begin{aligned}
R_{i, t, t+k}= & \alpha_{i}+\beta_{i} R_{m, t, t+k}+\gamma_{i} \theta_{t, t+k}+\varepsilon_{i, t, t+k} \\
\gamma_{i} \theta_{t, t+k}= & \gamma_{C A, i} \theta_{C A, t, t+k} * D_{C A, i}+\gamma_{E U, i} \theta_{E U, t, t+k} * D_{E U, i}+\gamma_{U K, i} \theta_{U K, t, t+k} * D_{U K, i}+\gamma_{A S, i} \theta_{A S, t, t+k} * D_{A S, i} \\
& +\gamma_{A U, i} \theta_{A U, t, t+k} * D_{A U, i}+\gamma_{L A, i} \theta_{L A, t, t+k} * D_{L A, i}+\gamma_{S A, i} \theta_{S A, t, t+k} * D_{S A, i}
\end{aligned}
$$

where $R_{i, t, t+k}$ designates the total return of firm $i$ over period $t$ until $t+k, R_{\mathrm{m}, t, t+k}$ the CRSP valueweighted stock market return over period $t$ until $t+k, \beta_{i}$ firm $i$ 's return sensitivity to market fluctuations, $\theta_{j, t, t+k}$ the realized movement in the region $j$ specific trade-weighted U.S. dollar exchange rate index over period $t$ until $t+k, D_{j, i}$ a dummy variable that takes the value 1 if firm $i$ has real activities in region $j, \gamma_{j, i}$ firm $i$ 's exposure to the realized change in the region $j$ specific trade-weighted U.S. dollar exchange rate index and $\varepsilon_{i, t, t+k}$ the white noise error term.

If, for firm $i$, the homoscedasticity of the error terms $\varepsilon_{i, t, t+k}$ is rejected, the model is extended with:

$$
\varepsilon_{i, t, t+k}=\mu_{i, t, t+k} *\left(h_{i, t, t+k}\right)^{1 / 2} \text { and } h_{i, t, t+k}=\delta_{i}+\tau_{i} \varepsilon_{i, t-k, t}^{2}+\nu_{i} h_{i, t-k, t}
$$

\begin{tabular}{|c|c|c|c|c|c|c|c|c|}
\hline & & \multirow[t]{2}{*}{$N$} & \multicolumn{2}{|c|}{ 1-Month horizon } & \multicolumn{2}{|c|}{ 3-Month horizon } & \multicolumn{2}{|c|}{ 12-Month horizon } \\
\hline & & & Mean; median & $\%$ signif & Mean; median & $\%$ signif & Mean; median & $\%$ signif \\
\hline Constant & $\alpha$ & 634 & $-0.011 ; 0.028$ & & $-0.029 ; 0.062$ & & $0.003 ; 0.208$ & \\
\hline \multirow[t]{2}{*}{$\begin{array}{l}\text { CRSP value-weighted market } \\
\text { index }\end{array}$} & $\beta$ & 634 & $1.3 ; 0.741$ & & $1.337 ; 0.896$ & & $1.15 ; 0.969$ & \\
\hline & & & $N(+) N(-)$ & & $N(+) ; N(-)$ & & $N(+) ; N(-)$ & \\
\hline $\begin{array}{l}\text { Bilateral US\$ exchange rate index } \\
\text { versus Canada }\end{array}$ & $\gamma_{\mathrm{CA}}$ & 441 & $18 ; 96$ & $25.85 \%$ & $20 ; 107$ & $28.80 \%$ & $21 ; 146$ & $37.87 \%$ \\
\hline $\begin{array}{l}\text { Trade-weighted US\$ exchange } \\
\text { rate index versus E.U. }\end{array}$ & $\gamma_{\mathrm{EU}}$ & 437 & $28 ; 45$ & $16.70 \%$ & $27 ; 55$ & $18.76 \%$ & $31 ; 117$ & $33.87 \%$ \\
\hline $\begin{array}{l}\text { Trade-weighted US\$ exchange } \\
\text { rate index versus U.K. }\end{array}$ & $\gamma_{\mathrm{UK}}$ & 447 & $32 ; 71$ & $23.04 \%$ & $34 ; 88$ & $27.29 \%$ & $53 ; 134$ & $41.83 \%$ \\
\hline $\begin{array}{l}\text { Trade-weighted US\$ exchange } \\
\text { rate index versus Asia }\end{array}$ & $\gamma_{\mathrm{AS}}$ & 420 & $6 ; 63$ & $16.43 \%$ & $7 ; 66$ & $17.38 \%$ & $28 ; 224$ & $60.00 \%$ \\
\hline $\begin{array}{l}\text { Trade-weighted US\$ exchange } \\
\text { rate index versus Australia }\end{array}$ & $\gamma_{\mathrm{AU}}$ & 260 & $31 ; 14$ & $17.31 \%$ & $36 ; 14$ & $19.23 \%$ & $54 ; 13$ & $25.77 \%$ \\
\hline $\begin{array}{l}\text { Trade-weighted US\$ exchange rate } \\
\text { index versus Latin America }\end{array}$ & $\gamma_{\mathrm{LA}}$ & 312 & $6 ; 41$ & $15.06 \%$ & $10 ; 66$ & $24.36 \%$ & $10 ; 182$ & $61.54 \%$ \\
\hline $\begin{array}{l}\text { Trade-weighted US\$ exchange rate } \\
\text { index versus South Africa }\end{array}$ & $\gamma_{\mathrm{SA}}$ & 114 & $4 ; 6$ & $8.77 \%$ & $13 ; 9$ & $19.30 \%$ & $15 ; 44$ & $51.75 \%$ \\
\hline Adjusted $R^{2}$ & & & & 17.6 & & 20.1 & & 38.6 \\
\hline
\end{tabular}

where $h_{i, t, t+k}$ denotes the conditional variance of the residuals; $\delta_{i}, \tau_{i}$ and $\nu_{i}$ unknown parameters; and $\mu_{i, t, t+k}$ represents the white noise error term.

The numbers are summary statistics of the cross-sectional distribution of the ordinary least squares parameter estimates, and the maximum likelihood (using the Berndt et al. (1974) algorithm) parameter estimates of Eqs. (1a)-(3a). $N *$ designate the numbers of firms with a documented significant exchange rate exposure to the regional currency index at the $5 \%$ level at least. $N$ are the numbers of firms that have activities in the corresponding geographical regions. Adjusted $R^{2}$ indicates the average of the adjusted $R^{2}$ statistics for all regressions. 
indeed to be taken into account in assessing the impact of exchange rate movements on a firm's competitive position. Given the complexity of the task, investors may find it difficult and may need time to assess all the long-run economic effects of currency fluctuations. While long-run exposure coefficients may translate this complex link between firm value and exchange rate movements, short-run exposure coefficients typically relate exclusively to known transactions as well as to known asset and liabilities positions, ignoring thus the expected future implications of the currency movement on firm value.

Regarding the sign of U.S. multinationals' exposure to the movements in the six different currency factors, several stylized facts are noteworthy: based on our findings Australia is only trading partner for which we document consistently more net-exporting relationships than net-importing links. On the opposite most U.S. multinationals active in Canada, Asia and Latin America tend to gain (suffer) from a depreciation (appreciation) of related currencies, indicating that they are primarily importing from these regions. While the fact that U.S. multinationals active in Canada, Asia and Latin America gain from a strengthening home currency may appear counterintuitive, it should be noted that the predominance of empirically documented importers is in line with previous empirical results (Bodnar and Wong, 2003; Muller and Verschoor, 2006a). It may moreover be linked to three types of explanations: (1) U.S. multinationals may actually set up foreign operations in Canada, Asia and Latin America for their local sales in these regions - depending hence on local raw products and production costs, (2) our selection procedure, using the Directory of American Firms Active in Foreign Countries, may have favored the selection of firms with foreign production subsidiary as this Directory is based on firms' ownership of fixed assets in foreign countries, (3) finally for net exporters the adverse valuation effects of a strengthening dollar may be offset by concurrent gains in a strengthening U.S. economy. As a well-performing U.S. economy is usually positively correlated with a stronger domestic currency, if among our sample there are net exporters, their response to exchange rate fluctuations may be partly counterbalanced and therefore more difficult to detect (Pritamani et al., 2004).

U.S. multinationals' foreign operations in Europe seem to be more balanced. Results indicate that approximately one third of the firms active in the euro-zone and in the U.K. may be considered as net exporters while the rest behaves like net-importing companies. These findings are in line with historical trade deficits of the U.S. vis-à-vis Europe - aggregate trade deficits that don't exclude however the presence of some important net-exporting U.S. multinationals in Europe.

To conclude the analysis of the sign of U.S. multinationals' currency exposures, we see that the sensitivity of U.S. companies to the South African rand is more difficult to characterize. It appears that most U.S. companies have at the three-month horizon net exporter exposures while most of them exhibit a long-term net importer exposure in the long run. At first sight, this outcome seems rather surprising. However the analysis of individual firm exposures across observation horizons reveals that only three firms out of 114 firms active in South Africa see the sign of their exposure change across horizons. It should be mentioned here that overall, among all U.S. multinationals included in our sample, only fifteen companies see their currency exposures change direction when lengthening the observation horizon. While the change in the sign of the exposure of these firms is definitively puzzling, we think that it might be related to the afore-mentioned discussion regarding investors' difficulty to assess accurately the total foreign exchange rate exposure of firms. Furthermore firms' transactions, translation and economic exposure do not necessarily match in direction or in magnitude (Bartov and Bodnar, 1994). A few U.S. multinationals seem to have short-term export (import) oriented cash flow gains as well as an aggregate foreign net asset (liability) position in their balance sheets. On the other hand, their long-term competitive position seems to gain (suffer) from appreciations of their home currency. The antagonism between these two exposure forces may under some circumstances be reinforced by the fact that the deteriorating effect of home currency appreciations is counterbalanced by the positive effects of a contemporaneously strengthening U.S. economy.

The sensitivity of U.S. multinationals to 'unanticipated' currency fluctuations is reported in Tables 5 and 6. We test whether - in line with the seminal definition of currency exposure - the use of 'unexpected' exchange rate movements in the estimation of foreign exchange risk exposure increases the precision and significance of U.S. multinationals' exposure estimates. 


\section{Table 5}

U.S. multinationals' foreign exchange risk exposure to unanticipated exchange rate movements - anticipations based on forward rates.

This table presents, for $k=1,3$ and 12 months, cross-sectional summary statistics of the estimation of the following regression model:

$$
\begin{aligned}
R_{i, t, t+k}= & \alpha_{i}+\beta_{i} R_{m, t, t+k}+\gamma_{i}^{\prime} \theta_{t, t+k}+\varepsilon_{i, t, t+k} \\
\gamma_{i}^{\prime} \theta_{t, t+k}= & \gamma_{C A, i}^{\prime} \theta_{C A, t, t+k} * D_{C A, i}+\gamma_{E U, i}^{\prime} \theta_{E U, t, t+k} * D_{E U, i}+\gamma_{U K, i}^{\prime} \theta_{U K, t, t+k} * D_{U K, i}+\gamma_{A S, i}^{\prime} \theta_{A S, t, t+k} * D_{A S, i} \\
& +\gamma_{A U, i}^{\prime} \theta_{A U, t, t+k} * D_{A U, i}+\gamma_{L A, i}^{\prime} \theta_{L A, t, t+k} * D_{L A, i}+\gamma_{S A, i}^{\prime} \theta_{S A, t, t+k} * D_{S A, i}
\end{aligned}
$$

where $R_{i, t, t+k}$ designates the total return of firm $i$ over period $t$ until $t+k, R_{m, t, t+k}$ the CRSP valueweighted stock market return over period $t$ until $t+k, \beta_{i}$ firm $i$ 's return sensitivity to market fluctuations, $\theta_{j, t, t+k}$ the unanticipated movement in the region $j$ specific trade-weighted U.S. dollar exchange rate index over period $t$ until $t+k, D_{j, i}$ a dummy variable that takes the value 1 if firm $i$ has real activities in region $j, \gamma_{j, i}^{\prime}$ firm $i$ 's exposure to the unexpected change in the region $j$ specific trade-weighted U.S. dollar exchange rate index and $\varepsilon_{i, t, t+k}$ the white noise error term.

If, for firm $i$, the homoscedasticity of the error terms $\varepsilon_{i, t, t+k}$ is rejected, the model is extended with:

$$
\varepsilon_{i, t, t+k}=\mu_{i, t-T, t} *\left(h_{i, t, t+k}\right)^{1 / 2} \text { and } h_{i, t, t+k}=\delta_{i}+\tau_{i} \varepsilon_{i, t-k, t}^{2}+\nu_{i} h_{i, t-k, t}
$$

\begin{tabular}{|c|c|c|c|c|c|c|c|c|}
\hline & & \multirow[t]{2}{*}{$N$} & \multicolumn{2}{|c|}{ 1-Month horizon } & \multicolumn{2}{|c|}{ 3-Month horizon } & \multicolumn{2}{|c|}{ 12-Month horizon } \\
\hline & & & Mean; median & $\%$ signif & Mean; median & $\%$ signif & Mean; median & $\%$ signif \\
\hline Constant & $\alpha$ & 634 & $-0.012 ; 0.029$ & & $-0.031 ; 0.067$ & & $-0.064 ; 0.212$ & \\
\hline \multirow[t]{2}{*}{ CRSP value-weighted market index } & $\beta$ & 634 & $1.298 ; 0.738$ & & $1.336 ; 0.889$ & & $1.066 ; 0.988$ & \\
\hline & & & $N(+) ; N(-)$ & & $N(+) ; N(-)$ & & $N(+) ; N(-)$ & \\
\hline $\begin{array}{l}\text { Bilateral US\$ exchange rate index } \\
\text { versus Canada }\end{array}$ & $\gamma_{\mathrm{CA}}$ & 441 & $19 ; 92$ & $25.17 \%$ & $23 ; 111$ & $30.39 \%$ & $22 ; 163$ & $41.95 \%$ \\
\hline $\begin{array}{l}\text { Trade-weighted US\$ exchange } \\
\text { rate index versus E.U. }\end{array}$ & $\gamma_{\mathrm{EU}}$ & 437 & $26 ; 46$ & $16.48 \%$ & $27 ; 58$ & $19.45 \%$ & $32 ; 117$ & $34.10 \%$ \\
\hline $\begin{array}{l}\text { Trade-weighted US\$ exchange } \\
\text { rate index versus U.K. }\end{array}$ & $\gamma_{\mathrm{UK}}$ & 447 & $51 ; 73$ & $27.74 \%$ & $49 ; 77$ & $28.19 \%$ & $50 ; 133$ & $40.94 \%$ \\
\hline $\begin{array}{l}\text { Trade-weighted US\$ exchange } \\
\text { rate index versus Asia }\end{array}$ & $\gamma_{\mathrm{AS}}$ & 420 & $7 ; 64$ & $16.90 \%$ & $5 ; 71$ & $18.10 \%$ & $24 ; 223$ & $58.81 \%$ \\
\hline $\begin{array}{l}\text { Trade-weighted US\$ exchange } \\
\text { rate index versus Australia }\end{array}$ & $\gamma_{\mathrm{AU}}$ & 260 & $29 ; 26$ & $21.15 \%$ & $41 ; 13$ & $20.77 \%$ & $47 ; 8$ & $21.15 \%$ \\
\hline $\begin{array}{l}\text { Trade-weighted US\$ exchange } \\
\text { rate index versus Latin America }\end{array}$ & $\gamma_{\mathrm{LA}}$ & 312 & $6 ; 38$ & $14.10 \%$ & $10 ; 66$ & $24.36 \%$ & $10 ; 182$ & $61.54 \%$ \\
\hline $\begin{array}{l}\text { Trade-weighted US\$ exchange } \\
\text { rate index versus South Africa }\end{array}$ & $\gamma_{\mathrm{SA}}$ & 114 & $5 ; 7$ & $10.53 \%$ & $9 ; 17$ & $22.81 \%$ & $17 ; 29$ & $40.35 \%$ \\
\hline Adjusted $R^{2}$ & & & & 18.5 & & 27.8 & & 39.8 \\
\hline
\end{tabular}

where $h_{i, t, t+k}$ denotes the conditional variance of the residuals; $\delta_{i}, \tau_{i}$ and $\nu_{i}$ unknown parameters; and $\mu_{i, t, t+k}$ represents the white noise error term.

The numbers are summary statistics of the cross-sectional distribution of the ordinary least squares parameter estimates, and the maximum likelihood (using the Berndt et al. (1974) algorithm) parameter estimates of Eqs. (4a)-(6a). $N *$ designate the numbers of firms with a documented significant exchange rate exposure to the regional currency index at the $5 \%$ level at least. $N$ are the numbers of firms that have activities in the corresponding geographical regions. Adjusted $R^{2}$ indicates the average of the adjusted $R^{2}$ statistics for all regressions. 


\section{Table 6}

U.S. multinationals' foreign exchange risk exposure to unanticipated exchange rate movements - anticipations based on survey expectations.

This table presents, for $k=1,3$ and 12 months, cross-sectional summary statistics of the estimation of the following regression model:

$$
\begin{aligned}
R_{i, t, t+k}= & \alpha_{i}+\beta_{i} R_{m, t, t+k}+\gamma_{i}^{\prime} \theta_{t, t+k}+\varepsilon_{i, t, t+k} \\
\gamma_{i}^{\prime} \theta_{t, t+k}= & \gamma_{C A, i}^{\prime} \theta_{C A, t, t+k} * D_{C A, i}+\gamma_{E U, i}^{\prime} \theta_{E U, t, t+k} * D_{E U, i}+\gamma_{U K, i}^{\prime} \theta_{U K, t, t+k} * D_{U K, i}+\gamma_{A S, i}^{\prime} \theta_{A S, t, t+k} * D_{A S, i} \\
& +\gamma_{A U, i}^{\prime} \theta_{A U, t, t+k} * D_{A U, i}+\gamma_{L A, i}^{\prime} \theta_{L A, t, t+k} * D_{L A, i}+\gamma_{S A, i}^{\prime} \theta_{S A, t, t+k} * D_{S A, i}
\end{aligned}
$$

where $R_{i, t, t+k}$ designates the total return of firm $i$ over period $t$ until $t+k, R_{m, t, t+k}$ the CRSP valueweighted stock market return over period $t$ until $t+k, \beta_{i}$ firm $i$ 's return sensitivity to market fluctuations, $\theta_{j, t, t+k}$ the unanticipated movement in the region $j$ specific trade-weighted U.S. dollar exchange rate index over period $t$ until $t+k, D_{j, i}$ a dummy variable that takes the value 1 if firm $i$ has real activities in region $j, \gamma_{j, i}^{\prime}$ firm $i$ 's exposure to the unexpected change in the region $j$ specific trade-weighted U.S. dollar exchange rate index and $\varepsilon_{i, t, t+k}$ the white noise error term.

If, for firm $i$, the homoscedasticity of the error terms $\varepsilon_{i, t, t+k}$ is rejected, the model is extended with:

$$
\varepsilon_{i, t, t+k}=\mu_{i, t-T, t} *\left(h_{i, t, t+k}\right)^{1 / 2} \text { and } h_{i, t, t+k}=\delta_{i}+\tau_{i} \varepsilon_{i, t-k, t}^{2}+\nu_{i} h_{i, t-k, t}
$$

\begin{tabular}{|c|c|c|c|c|c|c|c|c|}
\hline & & \multirow[t]{2}{*}{$N$} & \multicolumn{2}{|c|}{ 1-Month horizon } & \multicolumn{2}{|c|}{ 3-Month horizon } & \multicolumn{2}{|c|}{ 12-Month horizon } \\
\hline & & & Mean; median & \% signif & Mean; median & $\%$ signif & Mean; median & \% signif \\
\hline Constant & $\alpha$ & 634 & $-0.01 ; 0.024$ & & $-0.028 ; 0.058$ & & $-0.02 ; 0.245$ & \\
\hline CRSP value-weighted market index & $\beta$ & 634 & $1.25 ; 0.741$ & & $1.318 ; 0.907$ & & $1.177 ; 0.991$ & \\
\hline & & & $N(+) ; N(-)$ & & $N(+) ; N(-)$ & & $N(+) ; N(-)$ & \\
\hline $\begin{array}{l}\text { Bilateral US\$ exchange rate index } \\
\text { versus Canada }\end{array}$ & $\gamma_{\mathrm{CA}}$ & 441 & $28 ; 119$ & $33.33 \%$ & $29 ; 125$ & $34.92 \%$ & $28 ; 161$ & $42.86 \%$ \\
\hline $\begin{array}{l}\text { Trade-weighted US\$ exchange } \\
\text { rate index versus E.U. }\end{array}$ & $\gamma_{\mathrm{EU}}$ & 437 & $29 ; 63$ & $21.05 \%$ & $26 ; 63$ & $20.37 \%$ & $28 ; 110$ & $31.58 \%$ \\
\hline $\begin{array}{l}\text { Trade-weighted US\$ exchange } \\
\text { rate index versus U.K. }\end{array}$ & $\gamma_{\mathrm{UK}}$ & 447 & $49 ; 77$ & $28.19 \%$ & $48 ; 78$ & $28.19 \%$ & $52 ; 133$ & $41.39 \%$ \\
\hline $\begin{array}{l}\text { Trade-weighted US\$ exchange } \\
\text { rate index versus Asia }\end{array}$ & $\gamma_{\mathrm{AS}}$ & 420 & $9 ; 65$ & $17.62 \%$ & $5 ; 68$ & $17.38 \%$ & $26 ; 224$ & $59.52 \%$ \\
\hline $\begin{array}{l}\text { Trade-weighted US\$ exchange } \\
\text { rate index versus Australia }\end{array}$ & $\gamma_{\mathrm{AU}}$ & 260 & $31 ; 28$ & $22.69 \%$ & $39 ; 17$ & $21.54 \%$ & $54 ; 14$ & $26.15 \%$ \\
\hline $\begin{array}{l}\text { Trade-weighted US\$ exchange } \\
\text { rate index versus Latin America }\end{array}$ & $\gamma_{\mathrm{LA}}$ & 312 & $9 ; 60$ & $22.12 \%$ & $10 ; 70$ & $25.64 \%$ & $10 ; 179$ & $60.58 \%$ \\
\hline $\begin{array}{l}\text { Trade-weighted US\$ exchange } \\
\text { rate index versus South Africa }\end{array}$ & $\gamma_{\mathrm{SA}}$ & 114 & $12 ; 7$ & $16.67 \%$ & $12 ; 14$ & $22.81 \%$ & $19 ; 45$ & $56.14 \%$ \\
\hline Adjusted $R^{2}$ & & & & 23.9 & & 26.1 & & 40.1 \\
\hline
\end{tabular}

where $h_{i, t, t+k}$ denotes the conditional variance of the residuals; $\delta_{i}, \tau_{i}$ and $\nu_{i}$ unknown parameters; and $\mu_{i, t, t+k}$ represents the white noise error term.

The numbers are summary statistics of the cross-sectional distribution of the ordinary least squares parameter estimates, and the maximum likelihood (using the Berndt et al. (1974) algorithm) parameter estimates of Eqs. (4b)-(6b). Newey and West (1987) corrected standard deviations are in parentheses. $\mathrm{N}^{*}$ designate the numbers of firms with a documented significant exchange rate exposure to the regional currency index at the $5 \%$ level at least. $N$ are the numbers of firms that have activities in the corresponding geographical regions. Adjusted $R^{2}$ indicates the average of the adjusted $R^{2}$ statistics for all regressions. 
In Table 5 unanticipated exchange rate movements are defined with respect to forward-rate anticipations whereas in Table 6 unexpected exchange rate changes are defined with respect to consensus currency expectations as drawn from the Consensus Economics London survey. We note that, whatever definition adopted and in coherence with our empirical findings in Table 4, the significance of the impact of unanticipated currency movements on firm value increases when we lengthen the return horizon of our observations. In line with previous findings, both Tables 5 and 6 show that the longer the observation horizon the higher the average $R$ squared and the higher the percentage of significantly exposed firms. This stylized fact is verified independently on the way unanticipated movements are measured. It is similarly striking to observe that the relative proportion of significantly positively versus negatively exposed firms remain overall coherent across Tables 4-6.

When focusing on a comparison between specific columns of Tables 4-6, we see first of all that at the 1- and 3-month observation horizon the explanatory power of unanticipated exchange rate movements is stronger than the explanatory power of total realized currency changes. Obviously more firms are shown to have a statistically significant sensitivity to unanticipated exchange rate news than to total currency shocks. When focusing on the 3-month observation horizon we observe consistently in columns 2 of Tables 4-6 that the estimation of regression 6 (respectively 7) using unexpected exchange rate changes generate both larger adjusted $R$ squared measures as well as more precisely estimated currency exposure coefficients - the number of statistically significantly estimated coefficients increases. When using unanticipated currency changes, roughly $50 \%$ of the U.S. multinational corporations of our sample are significantly exposed to 'news' about at least one region-specific trade-weighted currency risk factor. ${ }^{22}$ This result is in contrast with the $38 \%$ of significantly exposed companies found when we estimated Eq. (6). ${ }^{23}$ The improvement of the detection of foreign exchange risk exposure associated with the increase in explanatory power of Eq. (7) compared to Eq. (6) reveals that U.S. shareholder wealth is less affected by movements in spot exchange rates than by the extent to which currency values change by more or less than had been expected by foreign exchange market participants. ${ }^{24}$ It therefore seems that in line with the efficient market hypothesis all the information readily available in foreign exchange rate expectations is incorporated in the value of U.S. multinationals before expectations' maturity. Investors thus make use of these publicly available forecasts disclosed by foreign exchange market experts.

It should however be emphasized that at the 1-month horizon the comparison between columns 1 of Tables 4-6 suggests that on average the link between firm value and unanticipated exchange rate movements as measured with respect to consensus exchange rate expectations is statistically much stronger not only compared to the link between firm value and realized currency movements - but as well much stronger than the link between firm value and unexpected

\footnotetext{
22 A company is defined as 'exposed' to exchange rate risk if its market-adjusted returns are statistically significantly affected by changes in currency values. Throughout the paper the $5 \%$ significance level is adopted.

${ }_{23}$ Across all 2,431 estimated coefficients less than $17 \%$ translate a statistically significant response to 'realized' exchange rate movements, while approximately $25 \%$ of these response coefficients give evidence of a significant relationship between stock returns and 'unexpected' currency shocks.

${ }^{24}$ To check the robustness of our findings we ran two additional series of regressions to verify whether expected components of exchange rate changes are significantly affecting stock returns when the impact is estimated - at the same time in the same regression - with the effect of unanticipated foreign exchange rate movements on firm value. These additional series of regressions include hence, simultaneously, on the one hand, unanticipated foreign exchange rate movements and, on the other, orthogonalized total foreign exchange rate shocks. (The orthogonalized total foreign exchange rate shocks - being estimated as the residuals of total foreign exchange rate movements when the latter are regressed on contemporaneous unanticipated foreign exchange rate movements - may intuitively be interpreted as the corresponding expected components of foreign exchange rate changes.) Our results confirm that at the 3-month observation horizon the incremental value relevance of the expected components of foreign exchange rate movements is very weak compared to the impact of unanticipated shocks on firm value. When using 1-month observation intervals the incremental impact of the expected components of foreign exchange rate movements is similarly negligible compared to the impact of unanticipated shocks when the latter are measured with respect to survey-based expectations. At the 1-month observation horizon, the incremental effect of the expected components of foreign exchange rate movements is however non-negligible when it is estimated simultaneously to the impact of unanticipated shocks measured with respect to forward rates. Results of these tests are available from the authors upon request.
} 
movements defined with respect to previously observed forward exchange rates. Surprisingly, there is only a small difference between US multinationals' sensitivity to total shocks and their sensitivity to the extent to which these shocks were unanticipated on forward markets. While almost 45 percent of our sample is significantly affected by the unanticipated component of the currency movements as measured with respect to the consensus survey expectation, the percentage of significantly exposed firms is approximately 35 percent in Table 5 . In line with this observation, both the average adjusted $R$ squared of our regression estimations and the number of significantly exposed companies increase when comparing Column 1 of Table 6 with their counterparts in Table 5. Our empirical findings reveal thus that investors do not pay more attention to the part of the exchange rate movement that was not anticipated on forward markets than to total currency shocks. The impact of both foreign exchange market signals seems approximately equivalent. ${ }^{25}$ On the other hand, results show that the message delivered by the distance between the realized shock and the expected shock as anticipated by the survey can be considered as significantly more informative than the message delivered by the distance between the realized shock and its anticipation on forward markets. ${ }^{26}$

If we assume that forward rates correspond to the most efficient translation of market participants' anticipations regarding the future evolution of exchange rates it seems counterintuitive that investors pay less attention to currency expectations as disclosed by forward markets than to a restricted sample of expectations disclosed by a series of panel members. To explain these features three differential reasons emerge. First the information contained in survey expectations may be considered as superior than the information disclosed by forward markets. Elliott and Ito (1999) have shown for instance that simple trading strategies based on survey expectations tend to outperform random walk- and forward-based strategies. Second, it is possible that in the short run the volatility of forward market makes it difficult for investors to understand the overall signal sent by the forward market. ${ }^{27}$ From a stock market investor's perspective the messages perceived from 1-month forward markets may indeed be regarded as varying too much in the short run to be instantaneously incorporated on stock markets. Finally, if we assume that forecasts disclosed by professional panelists are less influenced by specific market dynamics than forward market expectations are, it seems reasonable to think that investors feel more comfortable in interpreting the overall market sentiment expressed in a survey - while they could feel more uncomfortable in relying on expectations disclosed on a market. These differences in the characteristics of forward and survey-based expectations provide some tentative argumentation. It is however questionable why these distinctions may be of such an importance for 1-month expectations while their impact

\footnotetext{
${ }^{25}$ We would like to add that the robustness checks described in footnote 25 confirm these findings. Indeed at the 1 -month observation horizon the informational content of the expected components of foreign exchange rate movements is highly firm value relevant when their impact on firm value is investigated in addition to the impact of forward-rate-based unanticipated foreign exchange rate changes. However, in contrast, the relationship between these expected components and firm value is statistically weak when the relationship is analyzed contemporaneously to the link between survey-based unanticipated foreign exchange rate shocks and shareholder wealth. Results of these robustness checks are available from the authors upon request.

${ }^{26}$ As a robustness check we perform some kind of horse race test between the incremental impact on firm value of surveybased unanticipated FX movements when investigated in addition to the relationship between forward-rate-based unanticipated FX movements and firm value - and the incremental impact on firm value of forward-rate-based unanticipated FX movements when investigated in addition to the relationship between survey-based unanticipated FX movements and firm value. Our findings reveal that unanticipated exchange rate movements defined with respect to survey-based expectations are relatively more informative in terms of firm value relevance compared to unanticipated exchange rate movements defined with respect to forward rates. It appears that this result is particularly striking and statistically significant at the 1-month observation horizon. Results of these additional tests are available from the authors upon request.

${ }^{27}$ For all except one currencies included in our sample we observe that at the 1-month horizon, the standard deviations of the unexpected exchange rate movements calculated with respect to survey expectations are higher than the standard deviations of the unexpected exchange rate movements calculated with respect to forward rates suggesting that forward rates are consistently more volatile between January 1999 and December 2008 than consensus survey expectations. At the 3-month forecast horizon, these differentials in the degrees of fluctuations between forward rates and consensus expectations are less pronounced. Please refer to our discussion on page 14 as well as to the summary statistics presented in Table 3.
} 
vanishes at 3-month forecast horizons. Further research that goes beyond the scope of this article is needed.

Strikingly, in contrast with columns 1 and 2, columns 3 of Tables 4-6 are very similar. The numbers of significantly positively and negatively exposed firms to each of our currency indices are approximately identical. An in-depth analysis of individual firm exposures shows moreover that for none of our sample firms the sign of the exposure changes due to a differential currency index definition. The comparison of columns 3 of Tables 4-6 reveals that the estimation of the exchange rate exposure of US multinationals in the long term is not significantly affected by the way the exchange rate index is defined. This result indicates that investors do not react more significantly to the unanticipated part of the currency shock than they react to the total exchange rate movement. If investors do not see any informational difference between the raw realized shock and its unexpected component, this suggests that at disclosure the expectation has been considered from an informational perspective as irrelevant. Apparently when they are disclosed neither long-term anticipations observable on forward markets nor long-term forecasts disclosed by professionals are incorporated in stock markets.

A question that naturally arises is whether this finding can be explained by the possibility that longterm expectations are more heterogeneous. In other words, market participants disagree more about the future value of exchange rates that are further in the future than about those in the near future. ${ }^{28}$ Since any function of the consensus expectation cannot tell much about the existence of heterogeneous beliefs, it is necessary to look at individual expectations. The number of methods to measure or quantify heterogeneity is small because of the relatively scarcity of data on individual (survey) expectations. We use the coefficient of variation, defined as the cross-sectional standard deviation of the expectation divided by the cross-sectional average to measure and quantify the impact of observed heterogeneity in expectations on foreign exchange risk exposure. We do this for each currency at each point in time. This allows us to compare the measure of heterogeneity across currencies and horizons. Fig. 1 gives an overview of these coefficients of variation for the three most important currencies in our sample. Several findings need to be emphasized. First, similar to the empirical findings of Dominguez (1986), the dispersion in beliefs, as measured by the coefficient of variation, increases with the forecast horizon. Market participants obviously disagree more about the future path of the exchange rate as the horizon lengthens. Second, heterogeneity in beliefs is not constant over time. There are obviously periods of increased dispersion of beliefs (see Fig. 1). The lack of consensus regarding the future evolution of exchange rates may provide a preliminary indication that biases in individual expectations are likely to be of bigger concern as the forecast horizon is extended. This may naturally cause investors to be more reluctant to incorporate these expectations in their valuation process and explain why at a long observation-horizon investors don't see the informational value added by the observation of unanticipated currency movements over total realized movements. Given that long-run forecasts provide inconclusive signals to investors, these ambiguous informational content are not taken into account in the price formation process.

\footnotetext{
${ }^{28}$ This would be an interesting development, as it questions whether long-term expectations are mean-reverting. If expectations are mean-reverting, one would expect them to be homogeneous, since the market should be aware of the underlying fundamental exchange rate or in general the rate to which the exchange rate would revert. This issue calls for a better understanding of the mechanisms behind the formation of expectations and particularly the role of heterogeneity in beliefs in the foreign exchange market. (Anderson et al., 2005) Heterogeneity is indeed typically a missing factor when it comes to predicting returns and volatility. Moreover, little is yet documented about the microstructure of the foreign exchange market and the role of heterogeneous beliefs therein. More specifically, Ito (1990) was the first to document the existence of heterogeneous beliefs in the foreign exchange market and finds that market participants show evidence of wishful thinking in that their expectations of future Japanese yen/U.S. dollar rates reflect what they would like to see happen to the exchange rate. Exporters might, for instance, be biased toward a depreciation of the currency while importers are biased toward appreciation. Beine et al. (2007) furthermore find that this heterogeneity can be influenced by several market factors, like expected or unexpected official central bank intervention. Finally, there seems to be some evidence of sequential herding in the foreign exchange market as forecasters are connected to each other through leader and imitation patterns, though the evidence is not strong (Beine et al., 2003).
} 

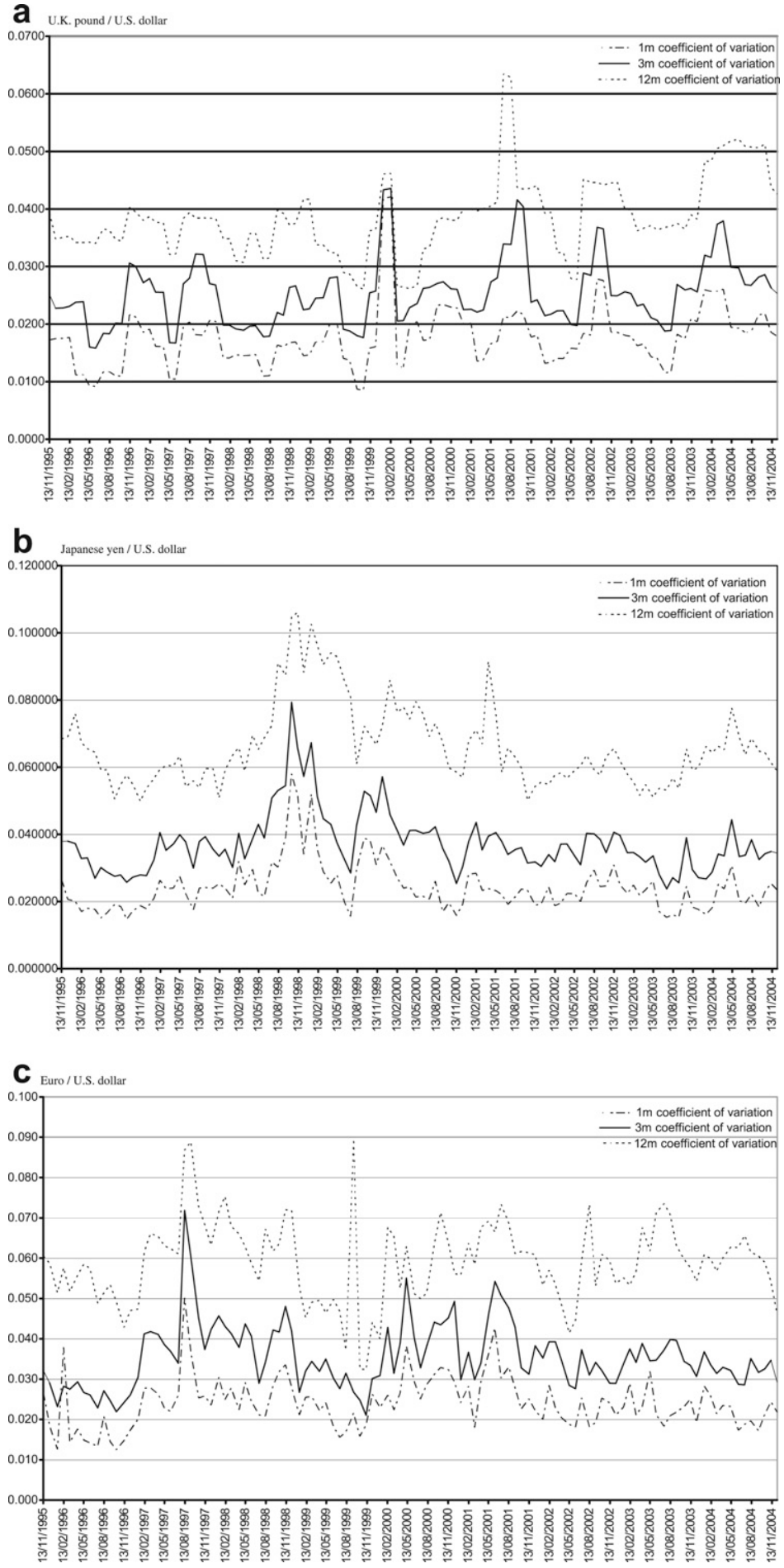

Fig. 1. a: U.K. pound/U.S. dollar. b: Japanese yen/U.S. dollar. c: Euro/U.S. dollar. 


\section{Concluding remarks}

This paper studies the effect of unexpected exchange rate movements on U.S. multinationals' stock returns. We recognize the inappropriate use of 'realized' exchange rate movements in testing the relationship between firm value and exchange rates, and propose an empirical model that examines the effect of unanticipated exchange rate movements on U.S. shareholder wealth from March 1999 till December 2009. Unlike most previous studies on exchange rate exposure, we explicitly consider innovations in exchange rate movements by taking into account short- and long-term expectations and their heterogeneity in our tests. By explicitly testing the implications of the generally accepted assumption that unexpected currency movements may be approximated by changes in realized spot exchange rates, we do not only provide an explanation for the weak evidence reported in previous empirical work but also increase our understanding of the economic significance and mechanism of foreign exchange risk exposure, thus generating valuable information for any financial or political decision dealing with foreign exchange risk.

Four key points emerge consistently from the empirical findings: (1) In line with previous findings the disaggregation of the worldwide trade-weighted U.S. dollar exchange rate index into seven regionspecific trade-weighted indices increases the precision and significance of exposure estimates. (2) The alternative model suggested in this paper that consists in estimating the relationship between stock returns and unanticipated foreign exchange movements leads to statistically stronger exposure estimates than the traditional model linking realized currency changes and stock returns. (3) When considering 1-month expectations empirical results show that truly exogenous individual survey measures of expectations are more informative when it comes to distinguish between 'realized' and 'unexpected' currency movements than forward rates. (4) While U.S. multinationals' sensitivity to both 'realized' and 'unexpected' exchange rate changes increases when the return horizon is extended, it should be emphasized that the documented difference in the statistical significance between exposure to unexpected currency movements and exposure to realized changes vanishes when lengthening the horizon. This result in conjunction with the empirically documented rise in the heterogeneity of foreign exchange rate expectations across increasing forecast horizons tends to suggest that the more market participants disagree about what will happen to the future level of currency values, the less investors and/or managers are likely to use these publicly available forecasts in their pricing and hedging decisions.

\section{Acknowledgments}

We gratefully acknowledge helpful comments from an anonymous referee and the Editor, as well as from participants at the 2007 Financial Management Association European meetings in Barcelona, Spain and the 2007 European Finance Association meetings in Ljubljana, Slovenia. The usual disclaimer applies.

\section{References}

Adler, M., Dumas, B., 1984. Exposure to currency risk: definition and measurement. Financial Management Summer, 41-50.

Amihud, Y., 1994. Exchange rates and the valuation of equity shares. In: Amihud, Y., Levich, R.M. (Eds.), Exchange Rates and Corporate Performance. Irwin, New York, pp. 49-59.

Anderson, E.W., Ghysels, E., Juergens, J.L., 2005. Do heterogeneous beliefs matter for asset pricing? Review of Financial Studies $18,875-924$.

Ang, A., Bekeart, G., Wei, M., 2007. Do macro variables, asset markets, or surveys forecast inflation better? Journal of Monetary Economics 54, 1163-1212.

Bartov, E., Bodnar, G.M., 1994. Firm valuation, earnings expectations, and the exchange rate exposure effect. Journal of Finance 49, 1755-1785.

Beine, M., Bénassy-Quéré, A., MacDonald, R., 2007. The impact of central bank intervention on exchange-rate forecast heterogeneity. Journal of the Japanese and International Economies 21, 38-63.

Beine, M., Bénassy-Quéré, A., Colas, H., 2003. Imitation amongst exchange-rate forecasters: evidence from survey data. CEPII Working Paper, 2003-08.

Berndt, E.K., Hall, H.B., Hall, R.E., Hausman, J.A., 1974. Estimation and inference in nonlinear structural models. Annals of Economic and Social Measurement 4, 653-666.

Bodnar, G.M., Wong, M.H.F., 2003. Estimating exchange rate exposures: issues in model structure. Financial Management 32 , 35-67. 
Bodnar, G.M., Gentry, W.M., 1993. Exchange rate exposure and industry characteristics: evidence from Canada, Japan and the USA. Journal of International Money and Finance 12, 29-45.

Bollerslev, T., Chou, R.Y., Kroner, K.F., 1992. ARCH modeling in finance. Journal of Econometrics 52, 5-59.

Cavaglia, S.M.F.G., Verschoor, W.F.C., Wolff, C.C.P., 1994. On the biasedness of forward foreign exchange rates: irrationality or risk premia. Journal of Business 67, 321-343.

Cavaglia, S., Verschoor, W.F.C., Wolff, C.C.P., 1993. Further evidence on exchange rate expectations. Journal of International Money and Finance 12, 78-98.

Choi, J.J., Prasad, A.M., 1995. Exchange risk sensitivity and its determinants: a firm and industry analysis of U.S. multinationals. Financial Management 24, 77-88.

Chow, E., Lee, W., Solt, M., 1997a. The economic exposure of U.S. multinational firms. The Journal of Financial Research 20 , 191-210.

Chow, E.H., Lee, W.Y., Solt, M.E., 1997b. The exchange-rate risk exposure of asset returns. Journal of Business 70, 105-123.

Döhring, B., 2008. Hedging and Invoicing Strategies to Reduce Exchange Rate Exposure. A Euro-area Perspective. Economic Papers 299. European Commission.

Dominguez, K.M.E., 1986. Are foreign exchange forecast rational? New evidence from survey data. Economics Letters 21, $277-281$.

Dominguez, K.M.E., Tesar, L.L., 2001a. A re-examination of exchange rate exposure. American Economic Review 91, 396-399.

Dominguez, K.M.E., Tesar, L.L., 2001b. Trade and exposure. American Economic Review 91, 367-370.

Elliott, G., Ito, T., 1999. Heterogeneous expectations and tests of efficiency in the yen/dollar forward exchange rate market. Journal of Monetary Economics 43, 435-456.

Engel, C., 1996. The forward discount anomaly and the risk premium: a survey of recent evidence. Journal of Empirical Finance 3, 123-192.

Frankel, J.A., Froot, K.A., 1987. Using survey data to test standard propositions regarding exchange rate expectations. American Economic Review 77, 133-153.

Frankel, J.A., Rose, A., 1995. A survey of empirical research on nominal exchange rates. In: Grossman, S., Rogoff, K. (Eds.), The Handbook of International Economics. North Holland, Amsterdam.

Gao, T., 2000. Exchange rate movements and the profitability of U.S. multinationals. Journal of International Money and Finance $19,117-134$.

He, J., Ng, L., 1998. The foreign exchange exposure of Japanese multinational corporations. Journal of Finance 53, $733-753$.

Ihrig, J., 2001. Exchange rate exposure of multinationals: focusing on exchange rate issues. International Finance Discussion Papers \#709.

Ito, T., 1990. Foreign exchange rate expectations: micro survey data. American Economic Review 80, 434-449.

Jongen, R., Verschoor, W.F.C., Wolff, C.C.P., 2008. Foreign exchange rate expectations: survey and synthesis. Journal of Economic Surveys 22, 140-165.

Jorion, P., 1990. The exchange rate exposure of U.S. multinationals. Journal of Business 63, 331-345.

Khoo, A., 1994. Estimation of foreign exchange exposure: an application to mining companies in Australia. Journal of International Money and Finance 13, 342-363.

Levi, M.D., 1994. Exchange rates and the valuation of firms. In: Amihud, Y., Levich, R.M. (Eds.), Exchange Rates and Corporate Performance. Irwin, New York, pp. 37-48 (Chapter 3).

Meese, R.A., Rogoff, K., 1983. Empirical exchange rate models of the seventies: do they fit out of sample? Journal of International Economics 14, 3-24.

Muller, A., Verschoor, W.F.C., 2006a. European foreign exchange risk exposure. European Financial Management 12, 195-220.

Muller, A., Verschoor, W.F.C., 2006b. Asymmetric foreign exchange risk exposure: evidence from U.S. multinational firms. Journal of Empirical Finance 13, 495-518.

Muller, A., Verschoor, W.F.C., 2006c. Foreign exchange risk exposure: survey and suggestions. Journal of Multinational Financial Management 16, 385-410.

Newey, W., West, K., 1987. A simple, positive semi-definite heteroskedasticity and autocorrelation consistent covariance matrix. Econometrica 55, 703-708.

Pritamani, M.D., Shome, D.K., Singal, V., 2004. Foreign exchange exposure of exporting and importing firms. Journal of Banking and Finance 28, 1697-1710.

Williamson, R.G., 2001. Exchange rate exposure and competition: evidence from the automotive industry. Journal of Financial Economics 59, 441-475. 